\begin{tabular}{c}
\hline Review of \\
ECONOMICS \\
and \\
INSTITUTIONS
\end{tabular}

\title{
The Effect of Industrialization on Children's Education. The Experience of Mexico
}

\author{
Anne Le Brun ${ }^{\bowtie}$ \\ Wellesley College
}

\author{
Susan R. Helper \\ Weatherhead School of Management \\ Case Western Reserve University
}

\author{
David I. Levine \\ University of California, \\ Berkeley
}

\begin{abstract}
We use census data to examine the impact of industrialization on children's education in Mexico. We find no evidence of reverse causality in this case. We find small positive effects of industrialization on primary education, effects which are larger for domestic manufacturing than for export-intensive assembly (maquiladoras). In contrast, teen-aged girls in Mexican counties (municipios) with more growth in maquiladora employment 1990-2000 have significantly less educational attainment than do girls in low-growth counties. These results shed light on literatures analyzing the impacts of industrialization, foreign investment, and intra-household bargaining power.
\end{abstract}

JEL classification: 125, L60, 014

Keywords: industrialization, Mexico, maquiladoras

$\square$ Address: Department of Economics - Wellesley College - 106 Central Street - Wellesley, MA 02481 (Phone 781-283-2988, Email: alebrun@wellesley.edu).

\section{Recommended Citation}

Le Brun, A., Helper, S., \& Levine. D.I. (2011). The Effect of Industrialization on Children's Education. The Experience of Mexico. Review of Economics and Institutions, 2(2), Article 1. doi: 10.5202/rei.v2i2.31. Retrieved from http://www.rei.unipg.it/rei/article/view/31 


\section{Introduction}

During the early 1990s Mexico was a poster child for the "Washington Consensus" of export-led manufacturing growth (Naim, 2000; Hanson, 2004). Mexico both increased its manufacturing employment by more than half and shifted from an emphasis on import substitution to export-oriented policies. The lion's share of the increase in manufacturing employment was due to export processing plants known as maquiladoras (or maquilas), whose employment more than tripled. Maquilas became the nation's most important source of export revenue, surpassing even oil $\left.\right|^{1}$

The "Peso crisis" in the middle of the decade made clear that exportoriented industrialization was not sufficient to create economic development. What remains unclear, though, is whether Mexico's industrialization strategy was beneficial or harmful to other dimensions of development such as education.

This question is important because the dimensions of development such as economic growth, health, and education do not always change in unison (Easterly, 1999). In fact, in some important early cases, industrialization harmed children's health (Nicholas and Steckel, 1991 and Floud and Harris, 1996).

Turning to education, the relationship between manufacturing growth and education is ambiguous. Industrialization may increase education by increasing parents' incomes, public sector revenues, returns to skill, and (by promoting urbanization) children's access to schools. At the same time, growth in manufacturing jobs can reduce education by increasing the opportunity costs of keeping children in school, reducing returns to skill (if manufacturing jobs are very low skilled), and inducing migration and other social disruption that can hinder school attendance.

Importantly for our purposes, some areas of Mexico received far more factories than others. Also, public school funding was determined by population, not local income, thus there is no relationship between the degree of industrialization of an area and the supply of education there. Our data also distinguish manufacturing for the domestic market, and export processing in maquiladoras. Thus we also examine the differential effects of globally-oriented industrialization.

We use household- and municipio-level data from the 1990 and 2000 Censuses ${ }^{2}$ We construct our sample to focus attention on those municipios at risk for industrialization. Thus we exclude Mexico City, which was losing manufacturing jobs. We also exclude very poor rural areas that were affected by a large welfare program (Progresa/Oportunidades) that had an independent effect on children's enrollment in school. Our main findings

1 Between 1992 and 1999, manufacturing employment increased by 53\%, and its maquiladora employment jumped by $259 \%$.

2 Municipios resemble U.S. counties. 
are: there is no evidence of reverse causality in plant location. Municipios with higher education in 1990 are not more likely to see an increase in maquila or domestic manufacturing employment than those with lower education. These results provide evidence against the hypothesis of endogenous factory location. Our specification controls for time-invariant municipio characteristics that affect children's outcomes, though we are still incapable of perfectly controlling for the possibility of time-varying municipio characteristics. To avoid problems of non-random migration, we focus our analysis on non-migrant families, though our results change little when we include migrants.

Industrialization, particularly when domestically focused, is correlated with higher primary education. In our sample, the percent of the workforce employed in maquilas increased from $2.3 \%$ to $4.5 \%$ between 1990 and 2000. This industrialization is correlated with an increase in educational attainment for children aged between 7 and 12 of almost one week $(.022 \times$ $.833 \times 52)$. Had this same increased employment occurred in domestic manufacturing, the impact on primary education would have been more than twice as great. However, growth in maquila employment is significantly correlated with lower education â in particular, a doubling in maquiladora employment would lower education attainment by one week for teenager girls.

These effects are small, perhaps because manufacturing work is neither high-skilled nor well-paid relative to other occupations. Increases in manufacturing or maquila employment in a municipio do not have a statistically significant impact on household income in that municipio (though the sign is positive), or on skill premia (where the sign is negative). At the same time, maquilas dramatically increased the demand for women's labor. When mothers became employed in manufacturing, daughters dropped out of school, presumably to replace mother's labor in the household. This effect is absent when fathers became employed in manufacturing.

These results shed light on literatures relating to the social effects of industrialization, foreign investment, and intra-household bargaining power. These results suggest that industrialization, if it is focused on low-skill assembly-intensive manufacturing, does not increase returns to education. In contrast to previous literature, we find that providing income to women may reduce investments in children, if obtaining the income requires women to work outside the home and does not provide substitutes for women in household labor.

The rest of the paper is structured as follows. We first describe the process of maquila-led industrialization that Mexico underwent during the 1990s. We then turn to a literature review and theoretical description of how manufacturing, and maquila manufacturing in particular, may affect children's education, by affecting income, urbanization, and intra-household bargaining. In a third section, we present our empirical methods. We then 
describe our data, and our results.

\section{Industrialization and Maquiladoras in Mexico}

In this paper, we study the impact of manufacturing-based industrialization on children's outcomes. We distinguish two types of industrialization: manufacturing for the domestic (Mexican) market and export processing (maquiladoras). We analyze the case of Mexico in the 1990s because this was a period of rapid maquiladora growth in the country.3

Until the 1980s, Mexico pursued a relatively closed-border policy of import substitution industrialization (ISI). The major exception to this policy was the maquiladora program, a type of Export Processing Zone (EPZ). This program was started in Mexico in the second half of the 1960s, partly to absorb the Mexican labor force displaced by the United States' termination of the Bracero program (a temporary agricultural worker program in the United States). Under the maquiladora program, Mexico allowed tax- and tariff-free imports of intermediate goods into plants along the northern border, for assembly and immediate re-export. H $^{4}$ Until 1972 maquilas were by law confined to the northern border (Hanson, 2005).

Upon taking office in 1982, President Miguel de la Madrid began a process of trade and investment liberalization. This paved the way for the eventual signing of the North American Free Trade Agreement in 1994. The main impact of NAFTA was to commit Mexico firmly to a neoliberal regime, raising investor confidence (Hanson, 2004). This market opening led to dramatic growth of manufacturing in Mexico. Worth only 12 percent of exports in 1980, manufactured goods accounted for about 43 percent of Mexico's exports in 1990, and fully 83 percent of its exports by the year 2000 - a growth from $\$ 95.4$ billion real US dollars in 1990 to $\$ 138.9$ billion in 2000 (World Development Indicators, 2000) . $^{5}$

3 This is certainly not the only major change in Mexico's landscape during the 1990s. Indeed, the country was rocked by the Peso crisis of 1994 too. As a result of this crisis, wages fell significantly between 1990 and 2000 (despite increases in education). When deflated by Mexico's CPI, the average hourly wage in 1990 dollars declined for males from $\$ 1.33$ to $\$ 1.11$ and for females from \$1.24 to \$1.13 (Hanson, 2004).

4 When the North American Free Trade Agreement was implemented in 1994, the tariff advantages of maquilas were reduced, although significant tariff savings remained in place through the end of the period we study (2000). In addition, firms that registered as maquiladoras in Mexico gained access to a more streamlined paperwork process than other firms in Mexico, with the government agency SECOFI taking on the responsibility of registering the firm with many different agencies, for example. Maquiladoras also retained important tax advantages. On the other hand, maquiladoras face the obligation to maintain their inventory in-bond. The combination of these effects means that it is beneficial for firms to register as maquiladoras only if they plan to directly export most of their production (INEGI, 2004; Dussel Peters, 2005; Carrillo, personal communication, 2006).

5 Another consequence of the change in trade policy embraced by the de la Madrid administration was the erosion of Mexico City's privileged position. Under ISI, both the 
The maquila sector proved one of the main drivers of manufacturing growth during the 1990s. According to Ibarraran (2003), manufacturing employment grew by 53 percent between 1992 and 1999. In the same time period, maquila employment shot up by 259 percent. ${ }^{6}$ In 1992, 67 percent of manufacturing employment was in domestic firms, 21 percent was in traditional foreign firms and only 12 percent was in maquiladoras. By 1999, the domestic share had shrunk to 58 percent, the traditional foreign to 14 percent, while the share of maquiladora employment had soared to 29 percent. In both years, about $80 \%$ of the maquiladoras were foreign owned (Ibarraran, 2004, chapter 2 and Table 2A.2).

In our analysis, we distinguish "maquilas" from "domestic manufacturing" (both Mexican- and foreign-owned), following Ibarraran (2004). Domestic manufacturing is production for the domestic Mexican market. These facilities, many of which date to the ISI period, have relatively high local content, so either they or their suppliers perform most of the steps required to make the final product within Mexico. For example, domestic apparel manufacturing included design (selecting fabrics and other inputs, creating patterns, and cutting fabric), assembly (sewing pieces together to make a garment), and distribution (Hanson, 1995). Domestic automotive production involved making components (such as engines, gauges, and wiring), assembling them into finished vehicles, and then distributing them.

In contrast, maquiladoras specialized in just one stage of production, assembly. Inputs were imported (even as late as 2000 , only $2 \%$ of the value of materials came from Mexico; see Carrillo and Gomis, 2003), assembled in maquilas, and then exported. Thus, apparel maquilas simply sewed together pieces of fabric cut in the US. Automotive parts maquilas assembled products such as wiring harnesses, using wire, metal terminals, and plastic connectors imported from Japan or the US, and then exported the harnesses to the US for final assembly into vehicles (Helper, 1995).

\section{Literature Review}

Mexico's episode of rapid maquiladora-centered industrialization in the 1990s provides us with a setting in which to assess the short term effects of manufacturing on children's education. We first discuss in this section

supply of inputs and the main destination markets for products were within the country (aside from the EPZ project concentrated at the border). With one-quarter of the country's population located in and around Mexico City, this was a good place in which to concentrate production. As Mexico has shifted its focus to international markets, there was a significant increase in the benefits of being close to the US, which is both a major source of inputs, and a vast potential market for outputs (Hanson, 1995).

${ }^{6}$ Other sources of data reflect the same trend: the number of 18-65 year old employed in manufacturing grew by 45\% between 1990 and 2000, according to census data. Confidential data obtained by Pablo Ibarraran (2004) put the growth in maquiladora employment during the same period at $188 \%$. 
research on the impact of industrialization on development in general. We then discuss several channels by which non-maquila manufacturing growth may affect children's education, both positively and negatively. Finally, we repeat the exercise for maquila-based growth in manufacturing employment.

The cross-sectional literature has established strong positive correlations between measures of income and measures of well-being. Easterly (1999) summarizes this literature, noting that cross-sectional studies ignore the possibility of omitted differences across nations, and should therefore not be taken as evidence that growth increases well-being. Easterly also analyzes the within-country evolution of quality of life across time as a function of income growth. His study analyzes income growth, rather than industrialization specifically, but since industrialization and GDP growth are highly correlated, his conclusions apply to our question as well. Using fixed effects, first differencing or instrumental variables, Easterly finds the relationship between growth and quality of life is weaker than in the cross section. Fixed effects and first differences may exacerbate measurement error, but his findings raise a red flag about the validity of inferring causality from cross-sectional relationships.

Longitudinal case studies suggest industrialization need not improve well-being. A variety of evidence supports the contention that living standards fell during the British Industrial Revolution, especially in the 1830s and early 1840s (Nicholas and Steckel, 1991; Floud and Harris, 1996). Regarding education specifically, the evidence is mixed. For example, Goldin and Katz (1999) find that high school attendance in US was negatively correlated with the share of manufacturing employment in the state. 7 In contrast, Federman and Levine (2004) find that industrialization has had a positive impact on education at all levels in Indonesia.

The inconclusive findings on effects of industrialization on children's education suggest that there is room for further research in this area. Below we identify four channels through which a rising share of manufacturing employment could affect the demand for children's education: income, urbanization, family disruption, and education premia. We first discuss the potential relationship between domestic manufacturing and these channels, and then turn to the link between these channels and maquiladoras.

More manufacturing also leads to increased governmental income, which can increase the supply of education (for example, more classrooms and teachers). This effect is muted in Mexico, which had very centralized education financing during the period under consideration. Changes in manufacturing employment in a municipio had little effect on the number of teachers/student in that municipio, because tax revenues were distributed largely according to population (see table 5, column 19 below, and also

7 Goldin and Katz (1997) show that average educational attainment in the US in 1890 was 8 years - greater than the average for Mexico in 2000. 
Helper et. al., 2006).

\subsection{Domestic Manufacturing}

Income. Manufacturing is more productive than activities it replaces, and/or is an additional source of aggregate demand. Hence it raises income for families if workers have the bargaining power to share in productivity gains. Increased parental income raises demand for education if education is a normal consumption good, or if education is constrained by liquidity. However, if manufacturing raises wages and generates employment opportunities, it can raise the opportunity cost of staying in school. Indeed, in contrast to agriculture, which has pronounced peaks of labor demand that the school calendar is organized to accommodate, it may be harder to mix manufacturing work and schooling.

Family disruption. Manufacturing may provide attractive employment and income prospects which disrupt traditional family structures. By encouraging families to move to cities away from extended family support structures, and by encouraging women to work for pay rather than to engage in household production, industrialization may undermine traditional household mechanisms that support child rearing. If these traditional support structures for children are not replaced (e.g., if fathers do not stay home), then increased labor force participation of mothers may lead to less education for children, as there may be no one to ensure that children attend school, or to see that children do their homework. These negative effects may be particularly pronounced for older daughters, who may be expected to stay home and do chores, especially if there are not other adult women around to pick up the slack (Chant, 1994).

Education premia. The only kind of skill we (along with most economists) can measure is that conferred by formal education. Predictions here are theoretically ambiguous. Manufacturing intuitively has higher returns to book learning than does peasant agriculture. But there is heterogeneity within manufacturing, and many jobs are not designed to have a payoff to high school (Tendler, 2002). So manufacturing may increase the returns to basic literacy, but not to high school. If education premia rise with manufacturing, this provides an incentive to stay in school. Conversely, lower education premia (especially for high school) increase the opportunity cost of postponing entry into work.

Urbanization. Manufacturing often leads to more urbanization, because of agglomeration economies across businesses, and because achieving minimum efficient scale in one business requires a moderately large work force. Urbanization can benefit children by bringing them closer to schools and making schools more accessible. One the other hand, the speed of urbanization may also be important: fast population growth that outstrips construction of infrastructure, can lead to overcrowding of schools and poor 
quality of teachers, as well as to unhygienic conditions not conducive to learning.

\subsection{Maquiladoras}

The literature on Export Processing Zones' (EPZ's) effects on children's outcomes is scant. We can however explore what the conclusions of general papers on EPZ's would imply for children's outcomes. Below, we look at how each of the channels above might be different in the case of maquiladoras.

Income. Much literature finds that foreign employers pay higher wages. Consistent with this literature, Hanson (2007) finds that exposure to globalization (as measured by the share of foreign direct investment, imports, and maquiladoras in states' GDP) increased income levels in Mexico during the 1990s. However, as Hanson points out, maquiladoras are only one component of this measure, and the different components may not all have the same effect on wages. It is also possible that low-globalization states fared poorly because of globalization in other states; for example, states that provided food or manufactured goods to other Mexican states would find their incomes reduced when other states began to import these goods from abroad.

Looking directly at the impact of maquiladoras, Ibarraran (2004) finds that these plants pay less than other manufacturing employers (see below). An additional piece of evidence is that turnover at maquilas in the 1990s was extraordinarily high. A survey of employers conducted by Carillo (1993, p. 98) in 1993 in Ciudad Juarez, Tijuana and Monterey found the average turnover rate was over 30\% per month; in late 2000, it was still $10-12 \%$ per month (Hualde, 2001b). Clearly, employers were not attempting to pay efficiency wages (see also Helper, 1995).

Family disruption. In addition to affecting levels of income, maquila employment may affect who receives the income. A key characteristic of maquiladoras is their high share of female employment. There is a great deal of evidence that maquila owners had a direct preference for hiring women (Tiano, 1993; Helper, 1995). The preference for women existed "because they are more docile", one manager said (Helper, 1995). Early in our period, maquila employment was overwhelmingly female. But later, as the pool of "maquila-ready" women was exhausted, the percentages fell throughout the decade. Still, in 1999, while non-maquila manufacturing firms' employees were 29 percent female, 49 percent of the maquila labor force was female (Ibararran, 2003, 2004)..$^{8}$ In the 1980s, managers' ideal em-

${ }^{8}$ Note that according to Ibarraran, while maquiladoras paid $14 \%$ less on average than domestic firms for unskilled labor in 1992, by 1999 the gap had largely closed. During the 1990 s, turnover in maquilas was quite high in most cities (averaging over $100 \%$ per year). Helper (1995) argues that this high turnover was due in large part to the lack of seniority wage incentives. That lack, in turn, was maintained by an employer cartel that kept wages 
ployee was a young, single woman, because they felt that she would not be distracted by family responsibilities. But by the early 1990s, their preference had shifted toward married women, because they showed more stability (Tiano, 1993).

A number of papers have argued against a "unitary" model of family decision-making in which families pool income from all sources, and argued instead for a "bargaining" model, in which who gets the income affects family decisions. That is, family members are more able to exert their preference if they bring more income to the table. For example, some papers have found that increasing the amount of income in women's hands increases investment in children. For example, Duflo found that increased pension income given to grandmothers increased the heights of granddaughters (but not of grandsons) that lived with them, while pensions given to grandfathers had no effect on their grandchildren's height. Most empirical papers reject the unitary model, but evidence on the impact of women's bargaining power on educational investments is mixed (see Xu, 2007 for a review).

These studies do not look at the impact of increased income from labor; instead they look at pre-marital assets, the sex ratio in the marriage market, etc. The reason is that women's labor hours are usually strongly affected by intrafamily bargaining, so labor income is therefore endogenous. However, income that women receive for working outside the home may have different impacts on investment in children than does nonlabor income. Such employment by women may well have mixed effects on children's education. On the one hand, as discussed above, many women have a stronger preference for investing in children than their husbands do, and providing more income increases their bargaining power.

On the other hand, maquila employment may reduce children's educational attainment for several reasons. First, maquila employment separates women from their children, compared not only to women who are full-time homemakers but also compared to more traditional forms of women's employment such as running a market stall or performing agricultural work, where children are often present alongside their mothers. Second, maquila employment may also raise the opportunity cost of keeping girls in school, if they either are eligible for maquila jobs themselves $\left.\right|^{9}$ or are called upon to take over some of the working mother's chores at home. In Mexico during this time period, men rarely men stepped in to perform these chores, even when unemployed (Chant, 1994).

Working conditions at some maquiladoras may also pose health hazards or be more stressful than other forms of employment. Several studies in the

\footnotetext{
fixed at the minimum level allowed by law.

9 There seem to be fewer employment opportunities for children under 15 years old in maquiladoras than in other kinds of manufacturing. There is evidence that multinationals do not want the bad publicity that might come from hiring children, and that their production processes are less conducive to child labor (Barajas et. al., 2004).
} 
public health literature provide evidence that at least some maquilas create health hazards for employees (which could translate into health hazards for the children of women who work while pregnant). For example, Eskenazi et. al. (1993) compared women in Tijuana who worked in services to women who worked in maquilas making garments and electronic products. They found that the maquila workers' babies weighed significantly less at birth. The garment workers' babies weighed even less than the electronics workers', suggesting that the demands of the job may be a more important cause of the problem than was occupational exposure to pollutants (as electronics workers were probably exposed to more harmful emissions). Similarly, Denman (cited in Cravey, 1998) found that babies born to mothers who worked in maquilas had lower birth weights, due to chemical exposure and physical demands on the job than did mothers who worked in service industry. These papers are suggestive, but their evidence is not conclusive, as they may suffer from sample selection biases if maquilas hire less healthy employees than do service employers.

Education premia. Industrialization driven by trade opening, as in Mexico, has ambiguous effects on the returns to education. The standard trade model suggests Mexico will specialize in low-skill manufacturing as it integrates with the higher-skilled U.S. market. This specialization can reduce the returns to education. Alternative models (e.g., Feenstra and Hanson, 1997) can lead to rising demand for skills, as Mexico shifts to jobs which for Mexico are medium-skilled, even if for the US they fit into the category of relatively low-skilled jobs. Feenstra and Hanson (1997) find that in states with more maquiladoras, the wage differential between production and non-production workers grew over the 1980s. $1^{10}$ But studies using data for the 1990s do not connect maquiladoras to the rising skill premium. These scholars characterize maquiladoras as low-skill-intensive sectors, whose boom in the 1990s led to fast employment growth, but did not contribute to the rise in the skill premium 11

Some have argued that maquilas began in the late 1990s to include more skill-intensive activities (beyond assembly) (Carrillo et. al., 1998; Carrillo

10 Hanson (2004) provides two additional possible reasons for the rise in skill premium. First, low-skill sectors saw the steepest fall in protection in the early wave of liberalization. By the Stolper Samuelson theorem, this would lead to a widening of the wage gap between skilled and unskilled workers. Second, capital and skilled labor are complements, so that the inflow of capital into the export processing sector generated by trade liberalization led to a rise in demand for skilled labor, driving up the skill premium.

11 Ibarraran (2004) uses data from the ENESTYC (the National Survey of Employment, Salaries, Technology and Training in the Manufacturing Industries), and shows that maquiladora workers in 1992 had lower average skill, lower median wages (for every skill level), and lower capital-to-labor ratios than all other manufacturing. By 1999, maquiladoras' median wages by skill level had closed the gap with domestic non-maquiladora manufacturing, but the skills distribution of maquiladora workers remained lower than average for manufacturing and the capital-intensity of production remained much lower in the maquiladora sector. 
and Hualde, 1996). However, the percentage of maquiladora employees who were engineers or technicians as opposed to operators did not change over our period (INEGI, 2004; Hualde, 2001b). As Verhoogen (2008) notes, "Although there may have been a shift toward more skill-intensive activities within the maquiladora sector, it appears that the first-order consequence of the expansion of the sector was an increase in the demand for less-skilled labor." Maquiladoras require a minimum level of education, but this is either a 6th grade or less commonly an 8th grade diploma (Tiano, 1993; Helper, 1995). Such a policy would raise the demand for early education, but not for high school.

Urbanization. As discussed above, Mexico reversed course in the 1980s, moving from import substitution to neo-liberal growth policies, and this policy shift led to a dramatic increase in the attractiveness of investment in maquiladoras. Thus, to the extent that fast urbanization has bad effects on children, these effects should be particularly evident in areas with a high percentage of maquila employment, which saw a faster urbanization rate.

The bottom line is that the effect of maquiladora growth on demand for education is theoretically ambiguous.

\section{Methods}

In this section, we introduce the basic empirical model we will be estimating. We then review concerns about this model and our approaches to dealing with them.

\subsection{Basic Specification}

It is impossible to predict a priori the direction of industrialization's effects on children. This ambiguity motivates our empirical analysis. We use the following basic specification to assess the sign of manufacturing and maquiladoras' impacts on children:

$$
\begin{aligned}
{\text { School }- \text { yrs }_{i, m, t}=} & \alpha+\beta \% M F G_{m, t}+\phi \% M A Q_{m, t}+\gamma X_{i, m, t}+ \\
& \delta_{m} F E_{m}+\theta \text { year }_{2000}+ \\
& \lambda \% M F G_{m, 1990} \times \text { year }_{2000}+\pi \% M A Q_{m, 1990} \times \text { year }_{2000}+ \\
& \rho \text { School }- \text { yrs }_{m, 1990} \times \text { year }_{2000}+\epsilon_{i, m, t}
\end{aligned}
$$

where $i$ represents a child, $m$ is his/her municipio of residence, and $t$ is either 1990 or 2000. The dependent variable is the number of school years the child has completed. The variables $\% M F G_{m, t}$ and $\% M a q_{m, t}$ are the main variables of interest: they are the percentage of people aged between 18 and 65 in the municipio who are employed in non-maquila manufacturing and maquiladoras, respectively, at time $t$. The $X^{\prime}$ s are household and child characteristics, $F E_{m}$ are municipio fixed effects, and year 2000 is a dummy equal to 1 in the year 2000. We also attempt to control for effects of 1990 
characteristics on outcomes in the year 2000, by including in the year 2000 the lagged values of $\% M F G_{m}, \% M A Q_{m}$ and of the dependent variable's average value for the child's age group.

This specification is similar to an equation in changes, but allows us to combine household-level observations from 1990 with those from 2000.

\subsection{Potential Difficulties and Solutions}

The specification above faces a number of challenges. We list here the main issues, and our approaches to them.

\section{Table 1 - Testing for Endogenous Manufacturing/Maquiladora Location}

\begin{tabular}{|c|c|c|c|c|}
\hline \multirow[t]{2}{*}{ Dependent variable } & \multicolumn{2}{|c|}{$\begin{array}{l}\Delta \# \text { adults employed in maquila OR non-maquila } \\
\text { manufacturing } \mathrm{m} / \text { population }_{\mathrm{m}, 1990}\end{array}$} & \multicolumn{2}{|c|}{$\begin{array}{l}\Delta \# \text { adults employed in } \\
\text { maquilas }_{\mathrm{m}} / \text { population }_{\mathrm{m}, 1990}\end{array}$} \\
\hline & $(1)$ & $(2)$ & (3) & (4) \\
\hline Mean education $\mathrm{m}_{\mathrm{m}, 1990}$ & $\begin{array}{l}0.002 \\
(0.011)\end{array}$ & $\begin{array}{l}-0.005 \\
(0.010)\end{array}$ & $\begin{array}{l}0.009 \\
(0.012)\end{array}$ & $\begin{array}{l}0.015 \\
(0.012)\end{array}$ \\
\hline$(\text { Mean education })_{m, 1990}^{2}$ & $\begin{array}{l}-0.001 \\
(0.001)\end{array}$ & $\begin{array}{l}-0.000 \\
(0.001)\end{array}$ & $\begin{array}{l}-0.001 \\
(0.001)\end{array}$ & $\begin{array}{l}-0.001 \\
(0.001)\end{array}$ \\
\hline $\begin{array}{l}\text { Fraction of } 18-65 \text { year olds } \\
\text { employed in non-maquila } \\
\text { manufacturing } m, 1990\end{array}$ & $\begin{array}{l}0.413 * * * \\
(0.048)\end{array}$ & $\begin{array}{l}0.403 \\
(0.046)^{* * *}\end{array}$ & $\begin{array}{l}0.117 \\
(0.053)^{* *}\end{array}$ & $\begin{array}{l}0.065 \\
(0.051)\end{array}$ \\
\hline $\begin{array}{l}\text { Fraction of } 18-65 \text { year olds } \\
\text { employed in maquilas }, 1990\end{array}$ & $\begin{array}{l}0.032 \\
(0.024)\end{array}$ & $\begin{array}{l}0.025 \\
(0.024)\end{array}$ & $\begin{array}{l}0.525 \\
(0.027)^{* * *}\end{array}$ & $\begin{array}{l}0.520 \\
(0.027)^{* * *}\end{array}$ \\
\hline Fraction urban in 1990 & $\begin{array}{l}0.017 \\
(0.013)\end{array}$ & $\begin{array}{l}0.005 \\
(0.013)\end{array}$ & $\begin{array}{l}0.014 \\
(0.014)\end{array}$ & $\begin{array}{l}0.010 \\
(0.014)\end{array}$ \\
\hline $\begin{array}{l}\mathrm{D}=1 \text { if municipio is on North } \\
\text { border }\end{array}$ & $\begin{array}{l}-0.006 \\
(0.005)\end{array}$ & $\begin{array}{l}-0.009 \\
(0.005)^{*}\end{array}$ & $\begin{array}{l}0.030 \\
(0.006)^{* * *}\end{array}$ & $\begin{array}{l}0.034 \\
(0.006)^{* * *}\end{array}$ \\
\hline $\begin{array}{l}\text { Fraction of population } \\
\text { w/toilet in } 1990\end{array}$ & $\begin{array}{l}-0.060 \\
(0.017)^{* * *}\end{array}$ & ---- & $\begin{array}{l}0.043 \\
(0.019)^{* *}\end{array}$ & ---- \\
\hline $\begin{array}{l}\text { Fraction of population } \\
\text { w/sewage in } 1990\end{array}$ & $\begin{array}{l}0.003 \\
(0.011)\end{array}$ & --- & $\begin{array}{l}-0.040 \\
(0.013)^{* * *}\end{array}$ & ---- \\
\hline $\begin{array}{l}\text { Fraction of population } \\
\text { w/electricity in } 1990\end{array}$ & $\begin{array}{l}-0.010 \\
(0.028)\end{array}$ & & $\begin{array}{l}0.004 \\
(0.031)\end{array}$ & ---- \\
\hline Constant & $\begin{array}{l}0.056 \\
(0.034)\end{array}$ & $\begin{array}{l}0.037 \\
(0.031)\end{array}$ & $\begin{array}{l}-0.051 \\
(0.038)\end{array}$ & $\begin{array}{l}-0.048 \\
(0.034)\end{array}$ \\
\hline Observations & 405 & 405 & 405 & 405 \\
\hline R-squared & 0.33 & 0.30 & 0.71 & 0.70 \\
\hline
\end{tabular}

Notes: OLS, municipio-level regressions. Robust standard errors clustered at year $\times$ municipio, shown in parentheses. Significant at ${ }^{* *} 1 \%,{ }^{* *} 5 \%$ and ${ }^{*} 10 \%$ levels. All regressions are weighted using weights provided by IPUMS. Municipios with more than $10 \%$ of $\mathrm{HH}$ receiving Progresa/Procampo, and Municipios in Mexico City are excluded.

\subsubsection{Reverse Causality}

The first issue is the possibility of reverse causality, or endogenous factory location. It is possible that manufacturers seek out the most educated workers and therefore locate in municipios with high pre-existing educational attainment. If this were true, we would expect to see municipios with high educational levels in 1990 having more manufacturing employment growth from 1990 through 2000 than those municipios with poor 1990 education statistics. To assess whether this is the case, we regress the municipio's 1990-2000 growth in manufacturing employment (maquila or oth- 
erwise) on baseline (1990) indicators of (i) the municipio's average adult education and (ii) education squared. Positive and significant coefficients on these variables would suggest that there is indeed endogenous factory location. In the regression, we control for the percentage of the municipios that was urbanized as of 1990. We also include as controls baseline industrialization of the municipio and baseline infrastructure measures. We then repeat the analysis using as the dependent variable the municipio's 19902000 growth in maquiladora employment. As Table 1 illustrates, we find no significant relationship between baseline education indicators and industrialization (whether domestic or maquila). Thus, there is no strong evidence of endogenous factory location. These results are robust to a variety of specifications.

\subsubsection{Endogenous Migration}

Another challenge is the possibility of endogenous migration within Mexico. People with more skills and ambition may migrate from the countryside to cities with high industrial growth, sensing higher opportunities there; these people may also be more likely to invest in their children's education. This selective migration can generate a positive correlation between manufacturing and children's outcomes due entirely to selection into migration of the most able, and not due to a causal relationship between manufacturing and children's outcomes. On the other hand, it is also possible that the most desperate families, those least able to invest in their children, are those that migrate into areas of high factory growth. If so, the correlation between migration and children's outcomes would be a negative one and the true benefits of manufacturing growth would be greater than estimated.

To deal with this issue, we present all our results excluding families not currently residing in the Mexican state in which the mother was born. This does not change our results substantially; results including immigrant households are available upon request.

\subsubsection{Explanatory Variables Influenced by Industrialization}

A third issue is the joint determination of some of the right-hand side variables. In particular, some explanatory variables may be influenced by industrialization. For instance, employment of a female household member in the manufacturing sector affects the care that a child receives, but the employment of a female household member is likely affected by the degree of industrialization in the municipio. In our opinion, this need not be a problem. Any right-hand side variable that is endogenous to manufacturing in fact represents a "mediating channel" through which manufacturing affects children. Methodologically, the concern with this type of variable is that its correlation with manufacturing will lower the precision of our estimates, but from a practical stand-point, we are interested in this multicollinearity because it can help us pinpoint more precisely through what channels manufacturing is affecting children. 
We first present a parsimonious version of our basic specification, including in our regressions only those explanatory variables which are arguably exogenous to industrialization: child's age, percent of children in the household who are male, and mother's educational attainment, with the understanding that this parsimonious specification may suffer from omitted variable bias. We then repeat the regressions including a broader set of controls, some of which may be endogenous to industrialization.

\subsubsection{Omitted Factors}

A final and related difficulty with the basic specification presented here is that there could be omitted factors which determine both factory location and education in a municipio, even when the broader set of controls are included. If these factors are time-invariant, the inclusion of the municipio fixed effects in our basic specification deals with the problem. However, if there are time-varying municipio characteristics which determine both factory location and educational outcomes for children, our basic specification above (and that with more control variables too) will suffer from omitted variable bias. As no perfect instrument for manufacturing growth exists, the best we can do for now is to identify and control for the factors which could be differentially affecting municipios over time.

One example of time-varying municipio characteristics is the Oportunidades program. Oportunidades, launched in 1998 by the federal government (initially called Progresa), provides financial aid to families that keep their children in school and take them to clinics for regular health check-ups. At year end 1999, the program was in place for 2000 rural municipios, out of 2443 total municipios in Mexico (Skoufias, 2005). Because the program was a purely rural one in 2000 , there is likely to be a negative correlation in our 2000 data between municipios with high manufacturing employment and municipios with household that participate in Oportunidades. Using our basic specification, we could find that the coefficient on manufacturing intensity is negative, but it is possible that this would reflect the positive impact of Oportunidades in rural communities, rather than the negative effect of manufacturing in urban municipios. To deal with this issue, we remove from our sample all municipios in which more than ten percent of the household claim to receive Oportunidades benefits in 2000.

It is difficult to uncover and control for all factors which could be affecting both industrialization and children's outcomes differently in different municipios. However, it should be noted that if our analysis does suffer from omitted variable bias, the nature of the bias would have to be rather complicated to explain our results, as will become apparent below.

\subsection{Data}

Our main sources of data are the IPUMS (Integrated Public Use Microdata Series) 10 percent and 10.6 percent samples of Mexico's 1990 and 2000 censuses, respectively. 
Table 2 - Summary Statistics, Census 1990, 2000

\begin{tabular}{|c|c|c|c|c|c|c|}
\hline & \multirow{2}{*}{1990} & \multirow{2}{*}{2000} & \multicolumn{2}{|c|}{1990} & \multicolumn{2}{|c|}{2000} \\
\hline & & & Maquila & Non-maquila & Maquila & Non-maquila \\
\hline \# observations & 3039208 & 2805903 & 1619540 & 1419668 & 1707699 & 1098204 \\
\hline $\begin{array}{l}\text { Fraction of municipio } 18-65 \text { year olds employed in non-maquila } \\
\text { manufacturing }\end{array}$ & 0.052 & 0.051 & 0.053 & 0.051 & 0.050 & 0.055 \\
\hline Fraction of municipio $18-65$ year olds employed in maquilas & 0.023 & 0.045 & ---- & ---- & ---- & ---- \\
\hline $\begin{array}{l}\text { Fraction of municipio } 18-65 \text { year old women employed in } \\
\text { manufacturingg }{ }^{\dagger}\end{array}$ & 0.028 & $0.043 * * *$ & 0.036 & $0.018 * * *$ & 0.050 & $0.028^{* * *}$ \\
\hline $\begin{array}{l}\text { Fraction household } 18-65 \text { year old women employed in } \\
\text { maquila or non-maquila manufacturing }\end{array}$ & 0.043 & $0.074^{* * *}$ & 0.056 & $0.027 * * *$ & 0.086 & $0.047 * * *$ \\
\hline $\begin{array}{l}\text { Fraction household } 18-65 \text { year old men employed in maquila } \\
\text { or non-maquila manufacturing }\end{array}$ & 0.206 & 0.208 & 0.232 & $0.176 * * *$ & 0.229 & $0.158 * * *$ \\
\hline $\begin{array}{l}\text { Fraction of kids whose mother works in maquila or non- } \\
\text { maquila manufacturing }\end{array}$ & 0.029 & $0.068 * * *$ & 0.037 & $0.020 * * *$ & 0.078 & $0.045^{* * *}$ \\
\hline $\begin{array}{l}\text { Fraction of kids whose father works in maquila or non-maquila } \\
\text { manufacturing }{ }^{\dagger}\end{array}$ & 0.209 & $0.216^{* * *}$ & 0.235 & $0.180 * * *$ & 0.239 & $0.167 * * *$ \\
\hline \multicolumn{7}{|l|}{ School years completed: } \\
\hline 7-12 year olds & 2.89 & $3.10 * * *$ & 2.94 & $2.84 * * *$ & 3.12 & $3.07 * * *$ \\
\hline $13-15$ year olds & 6.60 & $7.09 * * *$ & 6.73 & $6.46 * * *$ & 7.16 & $6.94 * * *$ \\
\hline $16-18$ year olds & 8.02 & $8.89 * * *$ & 8.17 & $7.86 * * *$ & 8.99 & $8.68 * * *$ \\
\hline $19-21$ year olds & 8.58 & $9.66 * * *$ & 8.78 & $8.34 * * *$ & 9.79 & $9.36 * * *$ \\
\hline $22-25$ year olds & 8.62 & $9.67 * * *$ & 8.92 & $8.24 * * *$ & 9.82 & $9.35 * * *$ \\
\hline $26-45$ year olds & 7.09 & $8.99 * * *$ & 7.50 & $7.61 * * *$ & 9.25 & $8.39 * * *$ \\
\hline Mothers' average education & 5.51 & $7.26 * * *$ & 5.89 & $5.08 * * *$ & 7.56 & $6.59 * * *$ \\
\hline Mothers' average age & 40.3 & $41.4^{* * *}$ & 40.3 & $40.2^{* * *}$ & 41.40 & 41.40 \\
\hline Average household size & 4.80 & $4.18^{* * *}$ & 4.76 & $4.84 * * *$ & 4.15 & $4.23 * * *$ \\
\hline Average age of household head & 43.6 & $44.6^{* * *}$ & 43.4 & $43.7^{* * *}$ & 44.5 & $44.9 * * *$ \\
\hline Fraction of children w/ father home & 0.809 & $0.812^{* * *}$ & 0.821 & $0.803 * * *$ & 0.813 & $0.801 * * *$ \\
\hline Fraction of children $\mathrm{w} /$ mother home & 0.903 & $0.932 * * *$ & 0.908 & $0.898 * * *$ & 0.935 & $0.926 * * *$ \\
\hline Average log(earnings of $\mathrm{HH}$ head or spouse) & 7.98 & $8.01 * * *$ & 8.08 & $7.85 * * *$ & 8.11 & $7.77 * * *$ \\
\hline Fraction of households with toilets & 0.862 & $0.957 * * *$ & 0.910 & $0.807 * * *$ & 0.972 & $0.926 * * *$ \\
\hline Fraction of households with sewage & 0.702 & $0.817 * * *$ & 0.761 & $0.634 * * *$ & 0.856 & $0.731 * * *$ \\
\hline Fraction of households with electricity & 0.938 & $0.981^{* * *}$ & 0.952 & $0.923 * * *$ & 0.985 & $0.973 * * *$ \\
\hline Fraction of households that are urban & 0.882 & $0.900 * * *$ & 0.929 & $0.828 * * *$ & 0.932 & $0.827 * * *$ \\
\hline Fraction of household members $\leq 18$ years old & 0.382 & $0.331 * * *$ & 0.375 & $0.390 * * *$ & 0.327 & $0.339 * * *$ \\
\hline Fraction of household members $22-64$ years old & 0.467 & $0.518 * * *$ & 0.474 & $0.459 * * *$ & 0.523 & $0.505^{* * *}$ \\
\hline Fraction of household members $\geq 65$ years old & 0.069 & $0.081 * * *$ & 0.069 & 0.070 & 0.079 & $0.084 * * *$ \\
\hline Fraction of household members who are males & 0.467 & $0.465 * * *$ & 0.469 & $0.464 * * *$ & 0.467 & $0.462 * * *$ \\
\hline
\end{tabular}

Notes: Excludes immigrant households, Mexico City, and households in municipios with ¿10\% Oportunidades participation. Notes: $1990-2000$ or maquila-non maquila difference is significant at ${ }^{* *} 1 \%$, ${ }^{* *} 5 \%$ or ${ }^{*} 10 \%$ level. $\dagger$ Given that our maquila employment data is derived from a different survey, the only information we have for maquilas is percentage of the population in a municipio which is employed in maquiladoras. We can subtract this number from the percentage employed in manufacturing to obtain an estimate of the percentage of the municipio's population employed in non-maquila manufacturing. For all other manufacturing-related variables, we cannot distinguish between maquiladora and non-maquiladora employment.

Source: IPUMS 10\% samples of 1990 and 2000 Mexican Census.

We also have data on maquiladora employment levels by municipio in 1990 and 2000 (aggregated from maquiladora surveys conducted by INEGI, and made available to us by Pablo Ibarraran). We use this data to construct the percentage of 18-65 year old population in the municipio who are employed in maquiladoras. The census identifies people who work in manufacturing generally. By subtracting our maquiladora employment figures, we are thus able to come up with an estimate of the percent of 18-65 year old in the municipio who are employed in non-maquila manufacturing. These measures of maquiladora and non-maquila manufacturing intensity are our key measures of the degree and type of a municipio's industrialization. 
The outcome that interests us is educational attainment, i.e. school years completed. Summary statistics are presented in Table 2, for residents of 481 of Mexico's 2443 municipios. ${ }^{12}$ We have deleted from this data all the municipios that make up Mexico City (because by 1990, Mexico City was already undergoing a process of de-industrialization, which is not the phenomenon we are interested in studying), and all the municipios in which more than ten percent of households participate in Oportunidades or Procampo. ${ }^{13}$ We also exclude from this data immigrant families. Columns 3 through 6 contrast the means of variables in municipalities with no maquila employment to those in municipalities where maquiladoras have chosen to locate.

Our measure of income includes income to the household head and spouse, but not to other members of the household. It does not include income to children or other adults living in the household. It is unclear what happens to income earned by these household members; some studies find that most of teenagers' earnings is kept by them, while others find that the money is turned over to the household head (Tiano, 1993). In any case, our results do not change if income of children and other family members is included. Our income measure does not capture benefits, which were greater for formal sector employment like manufacturing (domestic or maquila) than they were for informal employment. Thus, we may be disproportionately underestimating income to manufacturing households. ${ }^{14}$ We do not include emigrant remittances; this omission would bias our results about manufacturing only if households participating in manufacturing were more likely to receive such remittances. There is no evidence that this is true; emigrants are not more likely to come from areas near the US border (Hanson, 2009).

12 In 1990, Mexico had only 2,402 municipios. To match 1990 and 2000 data at the municipio level, we have merged municipios which were created during the decade back into their origin municipio of 1990. Our final data set has 405 municipios. Where did these municipios go? First, we grouped the 600 municipios in the state of Oaxaca (each of which is tiny) into 20 larger districts, using code from Chris Woodruff (see Helper et al, 2006). Second, we dropped municipios with significant Progresa exposure (as described below), and third, we dropped all "Mexico City" municipios, which we defined as all municipios in the Distrito Federal plus 18 additional municipios in the Estado de Mexico that border the Distrito. We are left with 481 municipios, representing 32\% of the observations in the original sample.

13 The census asks respondents in 2000 if they receive Progresa (Oportunidades) or Procampo benefits. Thus, it is unclear, when we delete municipalities with high Oportunidades participation, whether we are not sometimes attributing to Oportunidades benefits received from Procampo. In any case, the average percent of 18-65 year old population employed in manufacturing (maquila or otherwise) is $12.5 \%$ in the municipalities we keep in our analysis, versus $6.3 \%$ in those we throw out as "significant" Progresa/Procampo recipients.

14 However, including a measure of benefits in household income would not increase our measure of skill premia in maquiladoras, since those workers are less educated than the average worker. 
The summary statistics on municipios with and without maquiladoras present a mixed picture. Growth in manufacturing during the 1990s was clearly focused in the maquiladora sector - its share of employment doubled during the 1990s, while the percent of 18-65 year old employed in nonmaquila manufacturing remained essentially unchanged. Average school years completed rose more quickly in municipios with no maquiladoras than in municipios with maquiladoras in 1990, but from a lower base.

Table 3 - Fixed Effects Estimates of Industrialization's Effect on Educational Attainment

\begin{tabular}{|c|c|c|c|}
\hline \multirow{3}{*}{$\begin{array}{l}\text { Dependent variable } \\
\text { Ages }\end{array}$} & \multicolumn{3}{|c|}{ Number of school years completed ${ }_{i, m, t}$} \\
\hline & 7-12 & $13-15$ & $16-18$ \\
\hline & $(1)$ & $(2)$ & (3) \\
\hline $\begin{array}{l}\text { Fraction } 18-65 \text { year olds employed in non-maquila } \\
\text { manufacturing } \mathrm{m,t}\end{array}$ & $\begin{array}{l}1.792 \\
(0.396)^{* * *}\end{array}$ & $\begin{array}{l}1.319 \\
(0.423)^{* * *}\end{array}$ & $\begin{array}{l}-0.15 \\
(0.631)\end{array}$ \\
\hline Fraction $18-65$ year olds employed in maquilas $m, t$ & $\begin{array}{l}0.833 \\
(0.250)^{* * *}\end{array}$ & $\begin{array}{l}0.56 \\
(0.254)^{* *}\end{array}$ & $\begin{array}{l}-0.359 \\
(0.337)\end{array}$ \\
\hline $\begin{array}{l}\text { Fraction } 18-65 \text { year olds employed in non-maquila } \\
\text { manufacturing } m, 1990 \times 2000 \text { Dummy }\end{array}$ & $\begin{array}{l}0.462 \\
(0.200)^{* *}\end{array}$ & $\begin{array}{l}0.643 \\
(0.244)^{* * *}\end{array}$ & $\begin{array}{l}0.368 \\
(0.349)\end{array}$ \\
\hline $\begin{array}{l}\text { Fraction } 18-65 \text { year olds employed in maquilas }{ }_{m, 1990} \times 2000 \\
\text { Dummy }\end{array}$ & $\begin{array}{l}0.509 \\
(0.093)^{* * *}\end{array}$ & $\begin{array}{l}0.703 \\
(0.096)^{* * *}\end{array}$ & $\begin{array}{l}0.797 \\
(0.136)^{* * *}\end{array}$ \\
\hline Dummy=1 if male & $\begin{array}{l}-0.101 \\
(0.004)^{* * *}\end{array}$ & $\begin{array}{l}-0.15 \\
(0.009)^{* * *}\end{array}$ & $\begin{array}{l}-0.116 \\
(0.019)^{* * *}\end{array}$ \\
\hline Mother's years of education & $\begin{array}{l}0.056 \\
(0.002)^{* * *}\end{array}$ & $\begin{array}{l}0.124 \\
(0.003)^{* * *}\end{array}$ & $\begin{array}{l}0.228 \\
(0.003)^{* * *}\end{array}$ \\
\hline Fraction of household kids who are male & $\begin{array}{l:}0.000 \\
-0.006\end{array}$ & \begin{tabular}{l|l}
-0.019 \\
-0.012
\end{tabular} & $\begin{array}{l}-0.038 \\
(0.015)^{* * *}\end{array}$ \\
\hline Year 2000 dummy & $\begin{array}{l}1.495 \\
(0.118)^{* * *}\end{array}$ & $\begin{array}{l}3.109 \\
(0.130)^{* * *}\end{array}$ & $\begin{array}{l}2.985 \\
(0.131)^{* * *}\end{array}$ \\
\hline Avg yrs of schooling of 7-12 yr olds in $1990 * 2000$ Dummy & $\begin{array}{l}-0.491 \\
(0.042)^{* * *}\end{array}$ & ---- & ---- \\
\hline Avg yrs of schooling of $13-15$ yr olds in $1990 * 2000$ Dummy & ---- & $\begin{array}{l}-0.446 \\
(0.020)^{* * *}\end{array}$ & ---- \\
\hline Avg yrs of schooling of $16-18 \mathrm{yr}$ olds in $1990 * 2000$ Dummy & ---- & ---- & $\begin{array}{l}-0.325 \\
(0.016)^{* * *}\end{array}$ \\
\hline Constant & $\begin{array}{l}2.087 \\
(0.026)^{* * *}\end{array}$ & $\begin{array}{l}5.269 \\
(0.030)^{* * *}\end{array}$ & $\begin{array}{l}6.800 \\
(0.040)^{* * *}\end{array}$ \\
\hline Observations & 696057 & 410131 & 380617 \\
\hline R-squared & 0.61 & 0.23 & 0.19 \\
\hline Test of joint significance of first two coefficients & 10.23 & 5.25 & 0.62 \\
\hline Test of equality of first two coefficients & 11.75 & 3.98 & 0.14 \\
\hline
\end{tabular}

Notes: all regressions exclude people living in Mexico City or municipios where at least $10 \%$ of the population receives Progresa/Procampo, and exclude all members of immigrant households. Regressions are OLS, and include age dummies, not shown. Standard errors, clustered at year $\times$ municipio, shown in parentheses. Significant at ${ }^{* * *} 1 \%,{ }^{* *} 5 \%$ and ${ }^{*} 10 \%$ levels. All regressions are weighted using weights provided by IPUMS. The test statistics are $\mathrm{F}$ statistics.

\subsection{Results}

We first present a parsimonious specification of manufacturing's effects on children's education, and then repeat the regressions with more control variables. 


\subsubsection{Results with Parsimonious Specification}

Table 3 presents the results from our basic specification, including municipio fixed effects and year dummies, and only those right-hand side control variables which are most clearly exogenous or predetermined (namely gender and age dummies, mother's education, and a control for the share of household kids who are male). The regressions are broken down by age group - we run one regression for 7-12 year old population (i.e., children of grade school age), one for children 13-15 years old (who should be in junior high) and one for children 16-18 years old, or of high school age. The table suggests that non-maquiladora and maquiladora industrialization are both associated with higher educational attainment for seven to 15 year old. The effects are not large; a doubling of a municipio's percent maquila employment, as occurred in the 1990s, would be correlated with about a week more of education; the effect of non-maquila manufacturing is twice as big as for maquilas. 15

The coefficients on both non-maquila manufacturing and maquila employment are negative but insignificant for 16 to 18 year old people. Given that school years are cumulative, one might expect that gains in schooling achieved early in life would translate into higher educational attainment throughout life. However, the fact that the coefficient for 16-18 year old is no longer significant implies that while non-maquila manufacturing and maquiladoras encourage early childhood education, they may discourage schooling for older children. Maquiladoras require a minimum level of education, but this is either a 6th grade or less commonly an 8th grade diploma (Tiano, 1993; Helper, 1995). Such a policy would raise the demand for early education and the opportunity cost of further education in the high-industrialization municipios relative to the low-industrialization municipios.16

As far as the other right hand side variables are concerned, historical non-maquila manufacturing and maquiladora employment underscore the effect of current non-maquila manufacturing and maquiladoras: in mu-

\footnotetext{
15 We have also averaged the data at the municipality-level and run first-difference regressions (including as controls lagged values of $\% M F G_{m}, \% M A Q_{m}$, and the dependent variables), and we find qualitatively similar results. We show here the individual-level regressions because these allow us to include more precise controls and will facilitate the causal-channel analysis. We cluster all errors with the interaction year $\times$ municipio. We have also run separate regressions for each year of age (rather than grouping children 7-12, for example) and also run all regressions using the number of school years completed relative to the average for the child's age, and results are very similar.

16 Of course it is possible also that manufacturing intensity is strongly correlated with urbanization, and it is the proximity to any kind of employment possibility, not just manufacturing jobs, that may take children in high-manufacturing-intensity municipios out of school earlier. In results available on request, when we include a dummy=1 if child lives in an urban environment in the regressions, the regression results do not change. This suggests that we are not wrongly attributing to industrialization an effect that is actually attributable to urbanization.
} 
nicipios which had high industrialization of either type in 1990, children between 7 and 15 had higher school years completed in 2000 ${ }^{17}$ As expected, maternal education is positively correlated with a child's educational achievement. As in many countries, boys have lower educational attainment than girls.

In Table 4, we reproduce the same regressions, distinguishing between girls (columns 1 through 3 ) and boys (columns 4 through 6). While both types of industrialization have benefits for primary school for both sexes, girls between 13 and 15 benefit only from domestic manufacturing, while boys benefit from both types of manufacturing. The detrimental effect of the municipio's maquiladora employment is particularly salient for 16-18 year old girls. For them, the coefficient on municipio maquiladora employment is not only negative but also significant; girls between 16 and 18 would lose more than a week of educational attainment if the percentage maquila employment in their municipio doubled.

Table 4 - Fixed Effects Estimates of Industrialization's Effect on Educational Attainment - Girls vs. Boys

\begin{tabular}{|c|c|c|c|c|c|c|}
\hline \multirow{3}{*}{$\begin{array}{l}\text { Dependent variable } \\
\text { Gender } \\
\text { Ages }\end{array}$} & \multicolumn{6}{|c|}{ Number of school years completed ${ }_{i, m, t}$} \\
\hline & \multicolumn{3}{|c|}{ Girls } & \multicolumn{3}{|c|}{ Boys } \\
\hline & $\begin{array}{l}7-12 \\
(1)\end{array}$ & $\begin{array}{c}13-15 \\
(2)\end{array}$ & $\begin{array}{c}16-18 \\
(3)\end{array}$ & $\begin{array}{c}7-12 \\
(4)\end{array}$ & $\begin{array}{c}13-15 \\
(5)\end{array}$ & $\begin{array}{c}16-18 \\
(6)\end{array}$ \\
\hline $\begin{array}{l}\text { Fraction } 18-65 \text { year olds employed in } \\
\text { non-maquila manufacturing } m, t\end{array}$ & $\begin{array}{l}2.012 \\
(0.422) * * *\end{array}$ & $\begin{array}{l}1.678 \\
(0.462) * * *\end{array}$ & $\begin{array}{l}-0.67 \\
-0.815\end{array}$ & $\begin{array}{l}1.629 \\
(0.411)^{* * *}\end{array}$ & $\begin{array}{l}1.035 \\
(0.575)^{*}\end{array}$ & $\begin{array}{l}0.527 \\
(0.694)\end{array}$ \\
\hline $\begin{array}{l}\text { Fraction } 18-65 \text { year olds employed in } \\
\text { maquilas } m, t\end{array}$ & $\begin{array}{l}0.662 \\
(0.258)^{* *}\end{array}$ & \begin{tabular}{l|l}
0.271 \\
-0.24
\end{tabular} & $\begin{array}{l}-1.095 \\
(0.373)^{* * *}\end{array}$ & $\begin{array}{l}1.025 \\
(0.263) * * *\end{array}$ & $\begin{array}{l}0.89 \\
(0.365)^{* *}\end{array}$ & $\begin{array}{l}0.517 \\
(0.432)\end{array}$ \\
\hline $\begin{array}{l}\text { Fraction } 18-65 \text { year olds employed in } \\
\text { non-maquila manufacturing } m, 1990 \times \\
2000 \text { Dummy }\end{array}$ & $\begin{array}{l}0.456 \\
(0.210) * *\end{array}$ & $\begin{array}{l}0.83 \\
(0.257) * * *\end{array}$ & $\begin{array}{l}0.823 \\
(0.382)^{* *}\end{array}$ & $\begin{array}{l}0.457 \\
(0.214)^{* *}\end{array}$ & $\begin{array}{l}0.411 \\
(0.316)\end{array}$ & $\begin{array}{l}-0.08 \\
(0.429)\end{array}$ \\
\hline $\begin{array}{l}\text { Fraction } 18-65 \text { year olds employed in } \\
\text { maquilas } m, 1990 \times 2000 \text { Dummy }\end{array}$ & $\begin{array}{l}0.484 \\
(0.104) * * *\end{array}$ & $\begin{array}{l}0.559 \\
(0.092) * * *\end{array}$ & $\begin{array}{l}0.639 \\
(0.241) * * *\end{array}$ & $\begin{array}{l}0.529 \\
(0.100) * * *\end{array}$ & $\begin{array}{l}0.841 \\
(0.156) * * *\end{array}$ & $\begin{array}{l}0.963 \\
(0.209)^{* * *}\end{array}$ \\
\hline \multicolumn{7}{|l|}{ Dummy $=1$ if male } \\
\hline Mother's years of education & $\begin{array}{l}0.052 \\
(0.002) * * *\end{array}$ & $\begin{array}{l}0.119 \\
(0.003) * * *\end{array}$ & $\begin{array}{l}0.227 \\
(0.004) * * *\end{array}$ & $\begin{array}{l}0.059 \\
(0.002)^{* * *}\end{array}$ & $\begin{array}{l}0.127 \\
(0.003) * * *\end{array}$ & $\begin{array}{l}0.228 \\
(0.004)^{* * *}\end{array}$ \\
\hline $\begin{array}{l}\text { Fraction of household kids who are } \\
\text { male }\end{array}$ & $\begin{array}{l}-0.117 \\
(0.008) * * *\end{array}$ & $\begin{array}{l}-0.279 \\
(0.018) * * *\end{array}$ & $\begin{array}{l}-0.274 \\
(0.021) * * *\end{array}$ & $\begin{array}{l}0.101 \\
(0.009)^{* * *}\end{array}$ & $\begin{array}{l}0.253 \\
(0.018) * * *\end{array}$ & $\begin{array}{l}0.248 \\
(0.021)^{* * *}\end{array}$ \\
\hline Year 2000 dummy & $\begin{array}{l}1.493 \\
(0.119) * * *\end{array}$ & $\begin{array}{l}3.456 \\
(0.128) * * *\end{array}$ & $\begin{array}{l}2.879 \\
(0.154)^{* * *}\end{array}$ & $\begin{array}{l}1.491 \\
(0.131)^{* * *}\end{array}$ & $\begin{array}{l}2.768 \\
(0.171)^{* * *}\end{array}$ & $\begin{array}{l}3.062 \\
(0.144)^{* * *}\end{array}$ \\
\hline $\begin{array}{l}\text { Avg yrs of schooling of } 7-12 \text { yr olds in } \\
1990 * 2000 \text { Dummy }\end{array}$ & $\begin{array}{l}-0.49 \\
(0.042) * * *\end{array}$ & ---- & --- & $\begin{array}{l}-0.492 \\
(0.045)^{* * *}\end{array}$ & ---- & --- \\
\hline $\begin{array}{l}\text { Avg yrs of schooling of } 13-15 \text { yr olds } \\
\text { in } 1990 * 2000 \text { Dummy }\end{array}$ & ---- & $\begin{array}{l}-0.495 \\
(0.020) * * *\end{array}$ & ---- & ---- & $\begin{array}{l}-0.401 \\
(0.026) * * *\end{array}$ & ---- \\
\hline $\begin{array}{l}\text { Avg yrs of schooling of } 16-18 \mathrm{yr} \text { olds } \\
\text { in } 1990 * 2000 \text { Dummy }\end{array}$ & ---- & ---- & $\begin{array}{l}-0.300 \\
(0.018) * * *\end{array}$ & ---- & ---- & $\begin{array}{l}-0.349 \\
(0.018)^{* * *}\end{array}$ \\
\hline Constant & $\begin{array}{l}2.13 \\
(0.027) * * *\end{array}$ & $\begin{array}{l}5.349 \\
(0.033) * * *\end{array}$ & $\begin{array}{l}6.876 \\
(0.051)^{* * *}\end{array}$ & $\begin{array}{l}1.919 \\
(0.028)^{* * *}\end{array}$ & $\begin{array}{l}4.948 \\
(0.038)^{* * *}\end{array}$ & $\begin{array}{l}6.468 \\
(0.049) * * *\end{array}$ \\
\hline Observations & 342644 & 205463 & 191955 & 353413 & 204668 & 188662 \\
\hline R-squared & 0.62 & 0.24 & 0.20 & 0.59 & 0.23 & 0.19 \\
\hline $\begin{array}{l}\text { Test of joint significance of first two } \\
\text { coefficients }\end{array}$ & 12.03 & 7.58 & 4.96 & 9.08 & 3.49 & 0.75 \\
\hline $\begin{array}{l}\text { Test of equality of first two } \\
\text { coefficients }\end{array}$ & 20.09 & 14.71 & 0.41 & 4.22 & 0.07 & 0.00 \\
\hline
\end{tabular}

Notes: all regressions exclude people living in Mexico City or municipios where at least $10 \%$ of the population receives Progresa/Procampo, and exclude all members of immigrant households. Regressions are OLS, and include age dummies, not shown. Standard errors, clustered at year $\times$ municipio, shown in parentheses. Significant at ${ }^{* * *} 1 \%,{ }^{* *} 5 \%$ and ${ }^{*} 10 \%$ levels. All regressions are weighted using weights provided by IPUMS. The test statistics are $\mathrm{F}$ statistics.

17 The effect extends to 16 to 18 year old for maquiladoras. 


\subsubsection{Results with Control Variables}

We are interested in identifying the channels through which industrialization affects the demand for children's education. In this section, we investigate the impact of the four causal channels discussed in the previous section (income, family disruption, skill premia, and urbanization). The goal is to see if in fact manufacturing employment growth did have the hypothesized impact of, for example, raising income. Thus, we regress the 1990-2000 change in each potential mediating variable on the change in manufacturing employment, controlling for certain baseline characteristics. The results of these regressions are presented in Table 5.

Before discussing these demand-side factors, we first point out that manufacturing and maquila growth did not affect the supply of education. Column 19 shows that increases in industrial employment did not affect teacherstudent ratios, consistent with the argument that, since Mexico financed schools centrally during this period, industrialization did not affect the supply of schooling.

Surprisingly, there is little evidence for three of the four causal channels on the demand side. An increase in either type of manufacturing employment does not increase income (including proxies for income such as parents' education, toilets, sewers and electricity; see cols. 9-13), does not increase urbanization (col. 1), and does not increase skill premia (cols. 2022).

The one channel that does operate as predicted is household structure. Increased maquila employment in the municipio increases the percentage of household females employed in manufacturing, and increases the percentage of children whose mother is employed in manufacturing (given that the mother is present in the home). An increase in either type of industrial employment is correlated with an increase in the likelihood that a child's father is employed in manufacturing, given that the father lives at home ${ }^{18}$

Having identified at least some of the potential mediating variables that are affected by industrialization, we now include them in our educational attainment regressions (Table 6 and Table 7). We find some support for the theory that more maquilas in a municipio leads to more women in a household being employed in manufacturing, and that this increase causes girls' education to suffer.

18 Note that effect of manufacturing growth on paternal industrial employment is smaller when the manufacturing growth is concentrated in the maquiladora sector. 

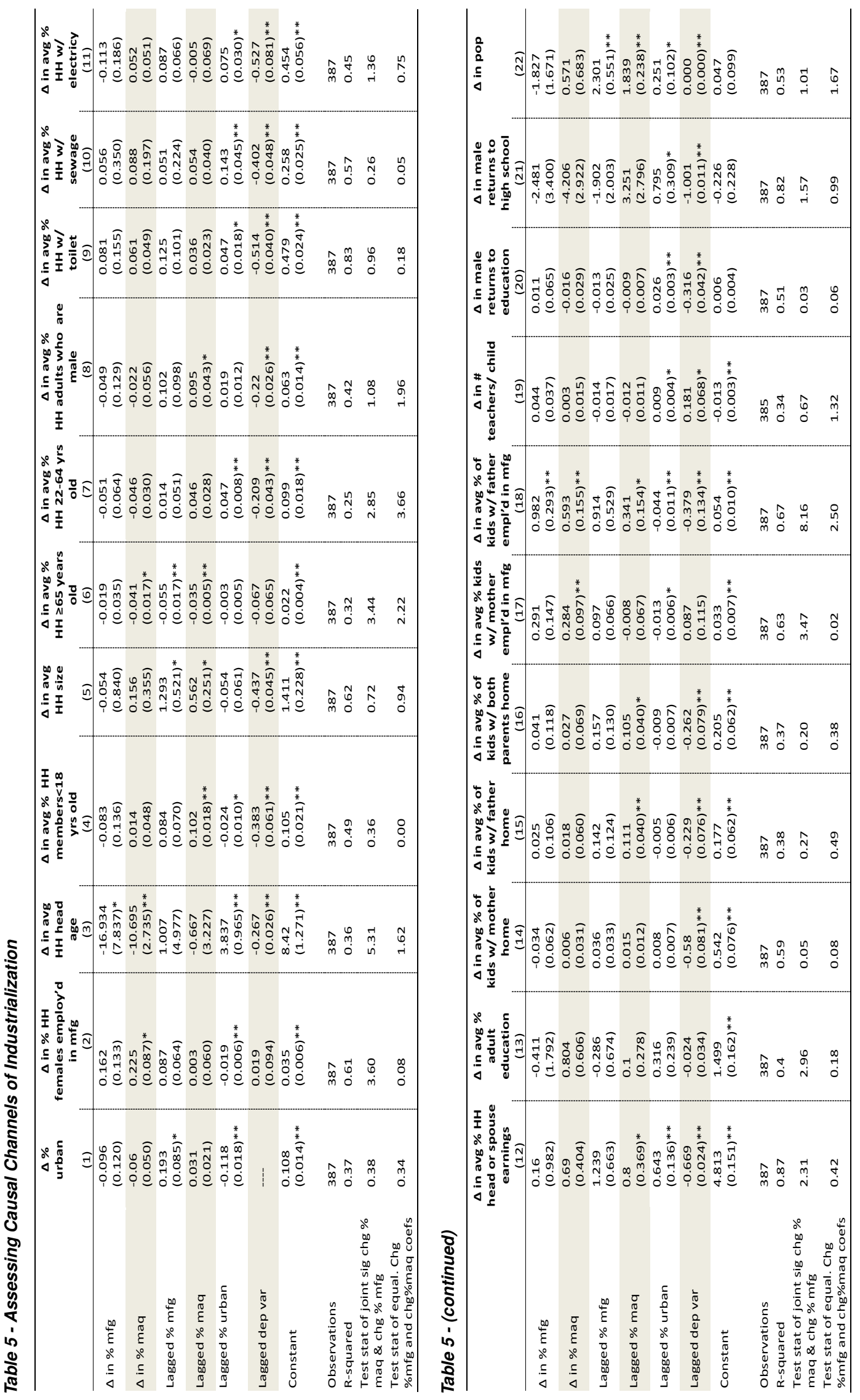

http://www.rei.unipg.it/rei/article/view/31 
Column 2 of Table 6 shows that the greater the percentage of household women employed in manufacturing, the lower is educational attainment for girls of all ages. Having more household women in manufacturing is bad for primary school boys, but good for older boys. At the same time, the greater the percentage of household men in manufacturing, the greater the education for both boys and girls below high school.

But few of our causal channels have much effect on the coefficients on the manufacturing variables, suggesting that we have not identified the important channels by which industrialization affects the demand for education. Controlling for the share of women in the household in manufacturing appears to explain some (but less than $20 \%$ ) of the negative effect of maquilas on high school girls' education. There are also some suggestive effects having to do with sanitation. Although increased manufacturing employment in a municipio does not predict greater toilet ownership, greater toilet ownership does explain about $1 / 3$ of the coefficient on domestic manufacturing for 13-15 year old girls. We find a similar effect for boys, in that an increased percentage of households in the municipio with sewage reduces the coefficient on maquila employment by $1 / 3$.

We are wary of attaching a causal interpretation to these coefficients. It is possible that improved hygiene in the household reduces the exposure of children to fecal particulates that could make them ill, and therefore decreases the likelihood that they will have to miss school due to disease. On the other hand, the relationship between toilets and child outcomes may not be causal: it is possible that the toilet dummy acts as a proxy for income of the family 19

The data allow us to identify whether a child's parent is employed in manufacturing only if that child's parent lives at home. If we want to assess the impact of female and male household manufacturing employment on children's outcomes on all children, not just those whose parents are at home, we are limited to including as controls the number of male and female adults employed in manufacturing in the household (i.e., we are not able to include dummies equal to one if father and mother are employed in manufacturing).

19 However, in regressions not shown, when the log of household head income is included as a control, the results for the toilet dummy persist. 


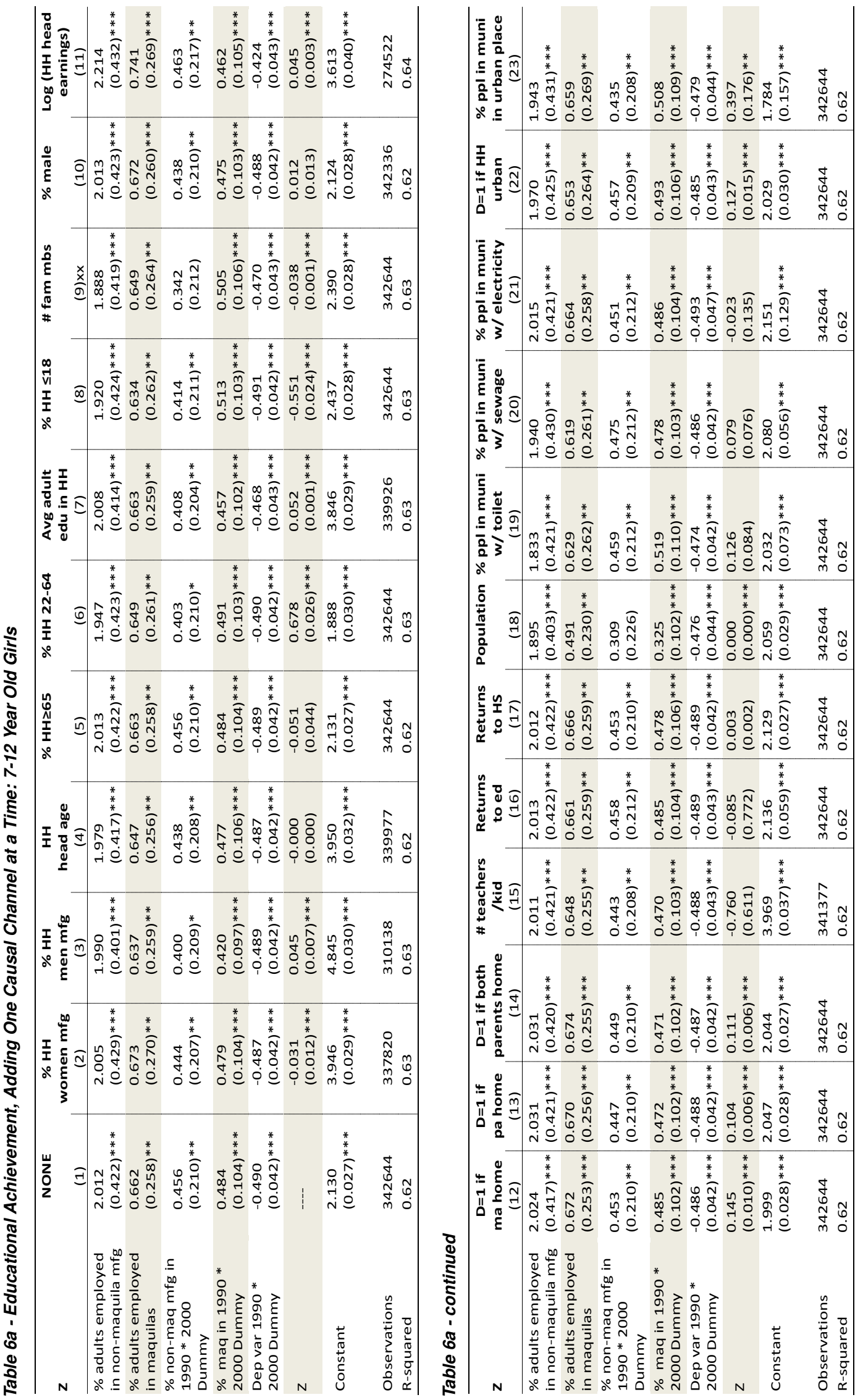

http://www.rei.unipg.it/rei/article/view/31 


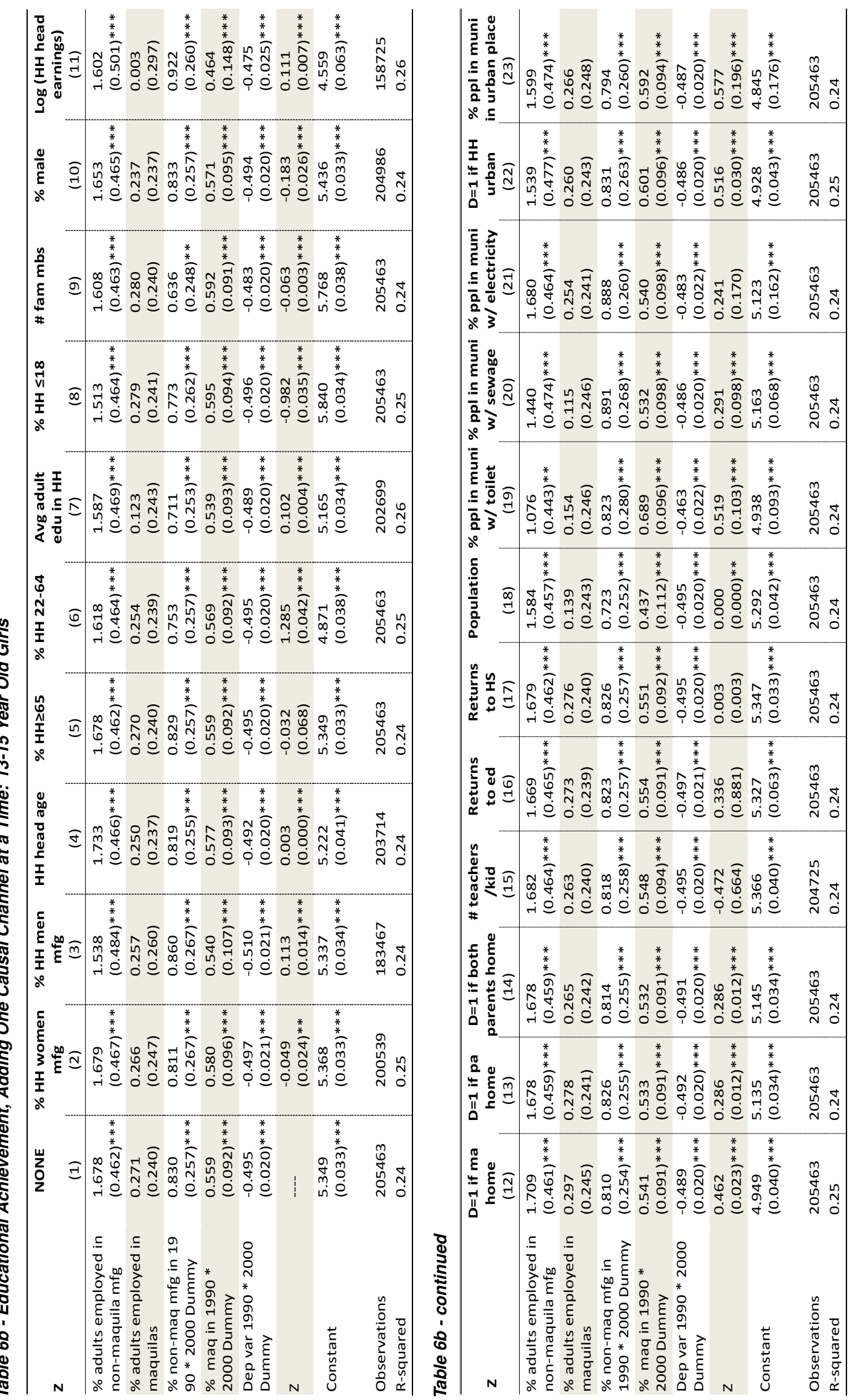




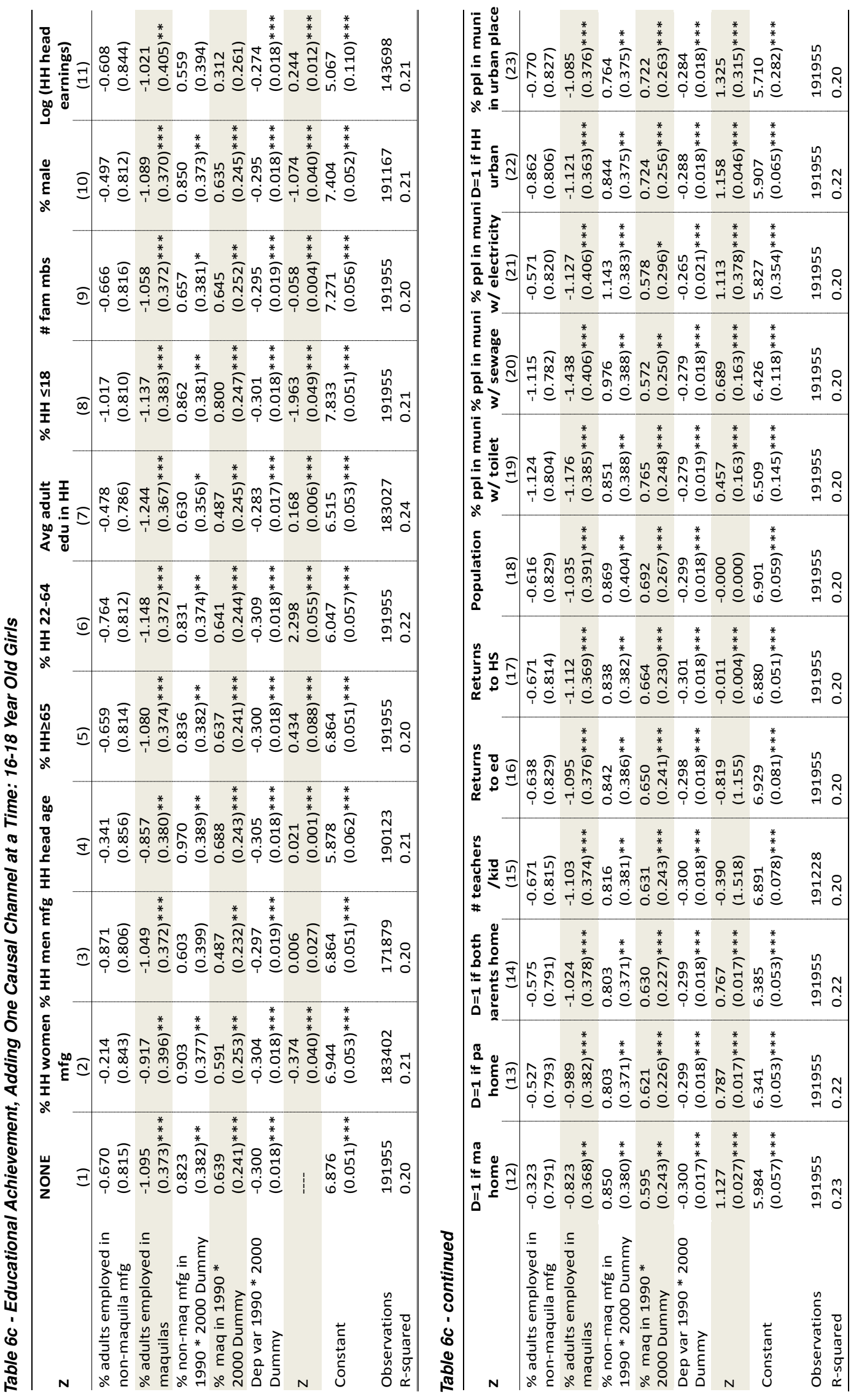

http://www.rei.unipg.it/rei/article/view/31 


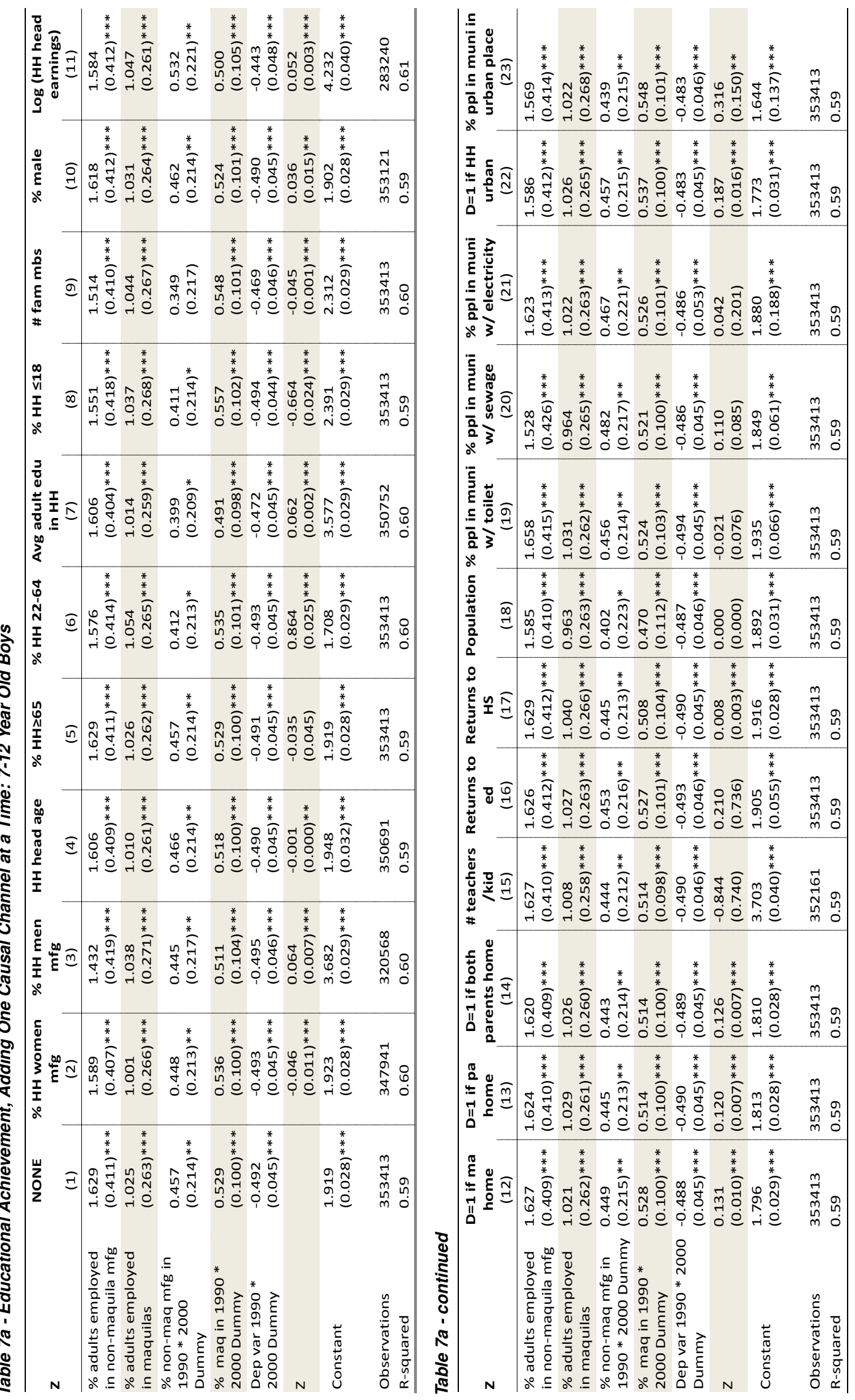




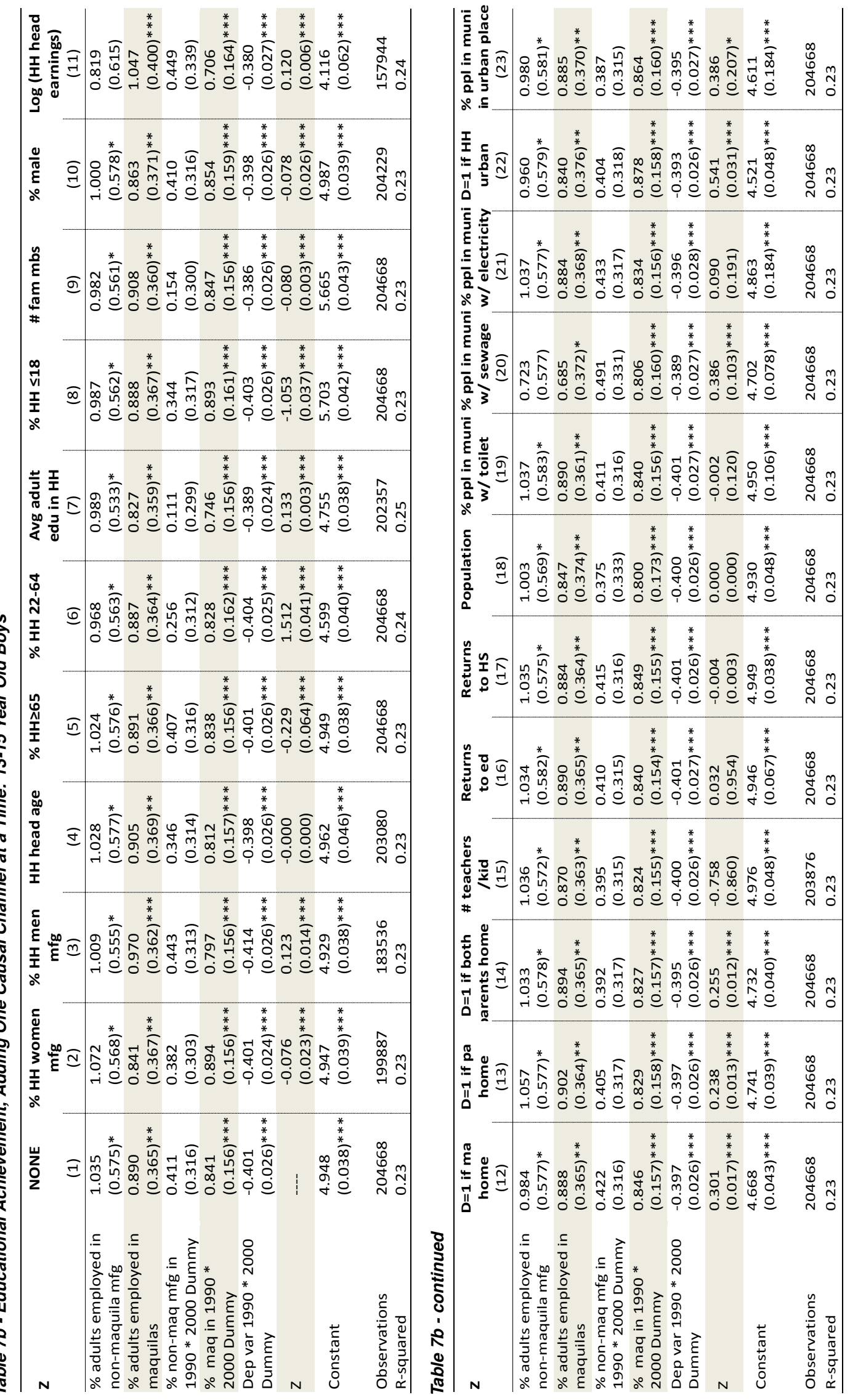




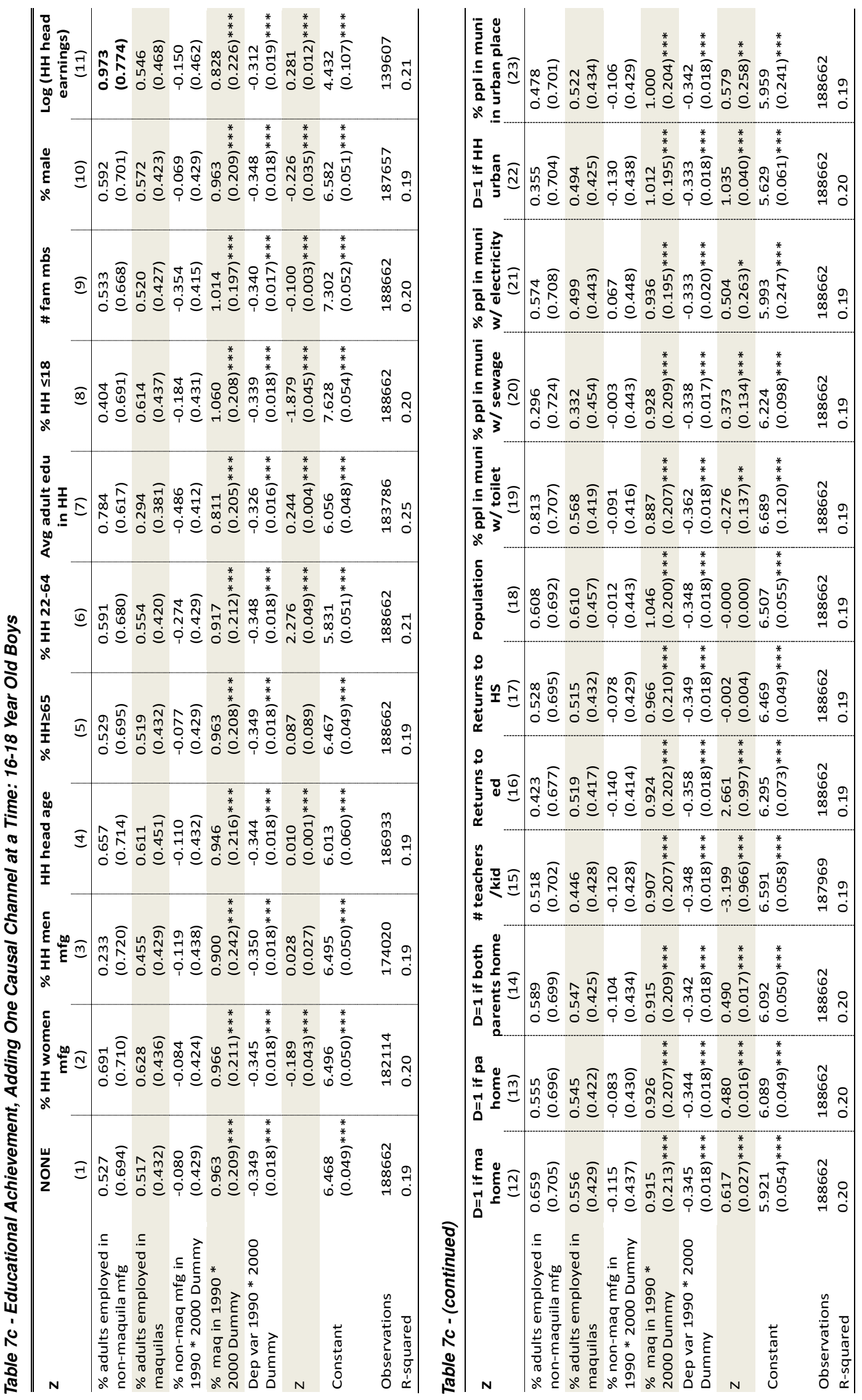


To the extent that caring for household children is a burden that all household women share, the negative impact that number of women in manufacturing has on children's outcomes is understandable. Of the many jobs women occupy in Mexico, working in a factory is among the likeliest to require the woman's separation from children of the household (this is in contrast to jobs such as, for example, shop keeper, artisan, or maid). It is therefore possible, that the more household females are employed in manufacturing, the fewer disciplinarians the children have to take care of them, ensure they do their homework and go to school. ${ }^{20}$

We have also undertaken the above analysis separating boys from girls (in results available upon request), and we find that among 16-18 year old in particular, it is the girls who are most strikingly affected by the gender composition of the household: the more women there are in the household, the better the educational outcomes of 16-18 year old girls. We also find that the greater the number of household adult females employed in manufacturing, the worse the educational outcomes for 16-18 year old girls. These findings are rather intuitive: the closest substitute for women in household chores are 16-18 year old girls. The more women the household has, and the fewer of these women that are occupied with the strict schedule of a manufacturing job, the less 16-18 year old girls in the household will have to assume the women's responsibilities (cleaning, cooking, caring for younger children). Surprisingly though, 16-18 year old girls whose own mother works in manufacturing have better educational outcomes than those girls whose mother lives with them but does not work in manufacturing. For this finding, we have no intuitive explanation.

In results not shown, we limit the sample to children whose father is at home, in order to be able to include a dummy for paternal manufacturing employment in the regression. When we do this, results change: paternal manufacturing employment is always associated with better children's outcomes: if a child's father is employed in manufacturing, that child is likelier to be enrolled in school and not to work, and will have higher average number of school years completed, regardless of age. In those regressions which include a dummy for paternal manufacturing employment, the impact of other household males' manufacturing employment on children's outcomes is negative: the more other men in the household (not the child's father) are employed in manufacturing, the lower the likelihood that the child is enrolled in school, the lower his school years attained, and the more likely he is to work. It is possible that in households with many males employed in manufacturing, children, following a sort of path dependence,

\footnotetext{
${ }^{20}$ If this "discipline vacuum" story is true, we might expect it to hit children in maquilarich municipios particularly hard, because maquiladoras are more intense in female labor than other manufacturing is. This claim would be verified if the coefficient on $\% M A Q_{m}$ were "less negative" in the school attainment regressions once we control for " $\mathrm{D}=1$ if ma employed in MFG". This is in fact the case, though not in a statistically significant sense.
} 
perceive manufacturing as the only job open to them, and act accordingly (dropping out of school, starting to work young, etc.). If this is the case, we might expect these results to be stronger for boys, who are bound to feel more "identified" with the men in the household than girls are. When we split the sample up by gender, we do find that the impact of non-paternal male manufacturing employment is much stronger on boys' likelihood of working than on girls, supporting our hypothesis.

\section{Conclusion}

Our analysis suggests that while non-maquila manufacturing and maquiladora employment are accompanied by small early improvements in school years completed, these gains in educational attainment are erased by the time children reach 16 years of age. In particular, girls aged 16-18 have less education, the more maquiladora employment there is in their municipio. Despite a decline soon after the 2000 Census, employment in maquilas remains a key source of income and exports for Mexico. Given their central role in Mexican industrialization, it is concerning that maquiladoras may act to deter older girls' educational attainment, whether it be by imposing more household responsibilities on them (as their grown-up counterparts join the maquila workforce) or by pushing them into the maquila sector themselves. Maquilas began in the late 1990s to include more skill-intensive activities (Carrillo et. al., 1998; Carrillo and Hualde, 1996). Such upgrading is necessary to compete with even lower wages in China and India, but it remains to be seen if the new focus towards more skill-intensive activities will generate enough demand for an educated work force to benefit children's and in particular girls' educational outcomes in the long run.

It is possible that maquilas contribute to a low-education trap for Mexico (Tendler, 2002). The purpose of the maquila program was to create jobs, not upgrading - but by increasing the opportunity costs of staying in school, maquilas may close off some development paths. As a United Nations report found, "transnational corporations bring technology appropriate to existing education levels-they do not invest in improving this level"(UNCTAD, 2001, quoted in Hualde, 2001a). Thus, when other nations can provide low-skilled labor more cheatly, multinationals shut their doors and go elsewhere- they do not invest in creating a higher-skilled work force in the first country.

It is interesting to compare the effects of industrialization on education with those of another program implemented around the same time-the Progresa/Oportunidades program, which paid families \$6-10 for each month their child consistently attended school (Skoufias and Parker, 2001). This federal government program served about $40 \%$ of the royal population. Careful studies comparing treatment and control groups found that the program increased educational attainment in primary grades by $10 \%$. For our 
population, that would lead to about about 15 weeks increased educational attainment-vastly more than the one week (later reversed for girls) that occurred when maquila employment doubled in Mexico during the 1990s.

Some aspects of the Mexican experience allow us to tease out relationships that are of broader theoretical interest. We are able to rule tut reverse causality in plant location; firms do not locate plants based on high education early in our period. In addition, national financing of schools means that manufacturing growth in a particular municipio does not bring increased taxes that would increase supply of education in that one area. Thus, our case allows us to shed light on how different kinds of manufacturing affect the demand for education.

Mexico has quite good data on its export processing zones (maquilas) allowing us to separate out different forms of foreign direct investment and their impacts on investment in children. The well-documented preference of maquila employers for women (and for other manufacturers to hire men) allows us no look at the role of labor income in intra-family bargaining. Our findings are not consistent with the "unitary" model of the household: children's outcomes depend a great deal on which parent gets a manufacturing job, and whether they are the same sex as that parent. When men get jobs in manufacturing, boys' education benefits; girls' education also benefits, but less strongly. When women get jobs in manufacturing, girls' education suffers, while teenage boys' benefits.

In addition, we separate out the impacts of industrialization on educational attainment at different ages and by boys and girls.

The story that emerges is that manufacturing does appear to increase demand for primary education, perhaps because of (small) increases in income, or to meet the maquilas' education requirements. Neither type of manufacturing has the expected positive effects on infrastructure (such as sewage), perhaps because these investments are financed nationally. Industrialization has a negative (though insignificant) impact on skill premia. The education effect is weaker for maquiladoras than for other manufacturing, for two reasons we can identify. First, the income effect is less positive. Second, maquiladoras are more likely to hire women, and the impact of a woman in the household working in manufacturing is negative.

The effect of maquilas in a municipio turns negative for high-school girls. This effect is consistent with a rising opportunity cost of staying in school for these young women, both because of the absence of their mothers and of their own ability to get these jobs.

These results suggest that foreign investment, if it is focused on assemblyintensive manufacturing, does not necessarily increase returns to education or the overall demand for education. Moreover, providing income to women does not necessarily increase investments in children, if obtaining the income requires women to leave the household and does not provide substitutes for women labor in the home. 


\section{References}

Barajas Ma. del Rosío, E., Almaraz, A.A., Carrillo, J.V., Contreras, O., Hualde, A.A. \& Rodriguez, C. (2004). Industria Maquiladora en México: Perspectivas del Aprendizaje Tecnológico-Organizacional y Escalamiento Industrial. Tijuana, Baja California, México: El Colegio de la Frontera Norte.

Carrillo, J., (Ed.) (1993). Condiciones en Empleo y Capacitacion en las Maquiladoras de Exportacion en Mexico. Tijuana, Baja California: Secretaria de Trabajo y Prevision Social y El Colegio de la Frontera Norte (1993)

Carrillo, J., \& Gomis, R. (2003) Los Retos de las Maquiladoras Ante la Pérdida de Competitividad. Comercio Exterior, 53(4). Retrieved from: http://revistas.bancomext.gob.mx/rce/magazines/19/3/Carrillo3741.pdf

Carrillo, J., Mortimore, M., \& Estrada, J.A. (1998). El Impacto de las Empresas Transnacionales en la Reestructuración Industrial de Mexico - El Caso de las Industrias de Partes para Vehículos y Televisores. CEPAL Serie Desarrollo Productivo 50.

Carrillo, J., \& Hualde, A.A. (1996). Maquilas de Tercera Generación. Espacios, 17(3). Retrieved from: http:/ / www.revistaespacios.com/

Chant, S. (1994). Women, Work and Household Survival Strategies in Mexico, 1982-1992: Past Trends, Current Tendencies. Bulletin of Latin American Research, 13(2). 203-233. doi:10.2307/3338275

Cravey, A.J. (1998). Women and Work in Mexico's Maquiladoras. Lanham: Rowman \& Littlefield Publishers, Inc.

Dussel Peters, E. (2005) Ser Maquila o No Ser Maquila, ¿Es Ésa La Pregunta? Retrieved from. http://dusselpeters.com/14.pdf.

Easterly, W. (1999.) Life during Growth: International Evidence on Quality of Life and Per Capita Income. World Bank WPS 2110 May.

Eskenazi, B., Guendelman, S., \& Elkin, E. P. (1993). A Preliminary Study of the Reproductive Outcomes of Maquiladora Workers in Tijuana, Mexico. American Journal of Industrial Medicine, 24(6). 667-676. doi:10.1002/ajim.4700240603

Federman, M., \& Levine, D.I. (2004). The Effects of Industrialization on Education and Youth Labor in Indonesia. Contributions to Macroeconomics, 5(1). Article 1. doi:10.2202/1534-6005.1243

Feenstra, R.C., \& Hanson, G.H. (1997). Foreign Direct Investment and Relative Wages: Evidence from Mexico's Maquiladoras. Journal of International Economics, 42(3-4). 371-393. doi:10.1016/S0022-1996(96)01475-4 
Floud, R., \& Harris, B. (1996). Health, Height and Welfare: Britain 17001980. (NBER historical paper No. 87). Retrieved from National Bureau of Economic Research website: http:/ /www.nber.org/papers/h0087.pdf

Goldin, C., \& Katz, L.F. (1999). Human Capital and Social Capital: The Rise of Secondary Schooling in America, 1910-1940. Journal of Interdisciplinary History, 29(4). 683-723. doi:10.1162/002219599551868

Hanson, G. (1995). Incomplete Contracts, Risk, and Ownership. International Economic Review, 36(2). 341-363. doi:10.2307/2527200

Hanson, G. (2004). What Has Happened to Wages in Mexico Since NAFTA? In Estevadeordal, T., Rodrick, D., Taylor, A., Velasco, A. (Eds.). FTAA and Beyond: Prospects for Integration in the Americas. Cambridge: Harvard University Press.

Hanson, G. (2005). Globalization, Labor Income, and Poverty in Mexico. (Working Paper No. 11027). Retrieved from National Bureau of Economic Research website: http:/ /www.nber.org/papers/w11027

Helper, S. (1995). Can Maquilas Be Lean? In Babson, S. (Ed.). Lean Work. Detroit: Wayne State University Press.

Helper, S., Levine, D.I., \& Woodruff, C. (2006). How Does Economic Liberalization Affect Investment in Education? Evidence from Mexico. EBRD Policy Conference on Institutional Development, Market Integration and Growth in Emerging Markets (June 30, 2006).

Hualde, A.A. (2001a). Formacion Educativa y Formación en la Empresa: un Balance sobre las Maquiladoras de la Frontera Mexicana. Documento de Trabajo, Santiago de Chile (March 2001). Website: www.eclac.org

Hualde A.A. (2001b). Aprendizaje Industrial en la Frontera Norte de México. La Articulación Entre el Sistema Educativo y el Sistema Productivo Maquilador. Tijuana, Baja California, México: El Colef/Plaza y Valdés Editores

Ibarraran, P. (2003). FDI and Wages in Mexican Manufacturing. Unpublished manuscript. University of California, Berkeley.

Ibarraran, P. (2004). Essays on Labor Markets and Economic Integration in Mexico. Unpublished PhD dissertation. University of California, Berkeley.

INEGI (2004). Banco de Informacion, Metadato, Industria Maquiladora de Exportacion. http://dgcnesyp.inegi.gob.mx/

Naim, M. (2000). Washington Consensus or Washington Confusion. Foreign Policy. Retrieved from: http://www.ucm.es/ 
Nicholas, S., \& Steckel, R.H. (1991). Heights and Living Standards of English Workers During the Early Years of Industrialization 1770-1815. Journal of Economic History, 51(4). 937-957. doi:10.1017/S0022050700040171

Skoufias, E. (2005). Progresa and its Impacts on the Welfare of Rural Households in Mexico. (Research Report n. 139). Retrieved from International Food Policy Research Institute website: http://www.ifpri.org/sites/default/files/publications/ab139.pdf

Skoufias, E., \& Parker, S.W. (2001). Conditional Cash Transfers and Their Impact on Child Work and Schooling: Evidence from the Progresa Program in Mexico. Economía, 2(1). 45-86. doi:10.1353/eco.2001.0016

Tiano, S. (1993). Patriarchy on the Line. Philadelphia: Temple University Press.

Tendler, J. (2002). The Fear of Education. (MIT working paper). Retrieved from: http://www.oecd.org/dataoecd/43/40/2489865.pdf.

Verhoogen, E. (2008). Trade, Quality Upgrading, and Wage Inequality in the Mexican Manufacturing Sector. Quarterly Journal of Economics, 123(2). 489530. doi:10.1162/qjec.2008.123.2.489

Xu, Z. (2007). A Survey on Intra-Household Models and Evidence. (MPRA paper n.3763). Retrieved form: http:/ / mpra.ub.uni-muenchen.de/3763/. 